\title{
Idiosyncratic Volatility Puzzle: Influence of Macro-Finance Factors
}

Nektarios Aslanidis, Charlotte Christiansen, Neophytos Lambertides and Christos S. Savva

CREATES Research Paper 2014-45 


\title{
Idiosyncratic Volatility Puzzle: Influence of Macro-Finance Factors*
}

\author{
Nektarios Aslanidis ${ }^{\dagger}$ \\ Universitat Rovira i Virgili, CREIP \\ Charlotte Christiansen \\ CREATES, Aarhus University \\ Neophytos Lambertides ${ }^{\S}$ \\ Cyprus University of Technology \\ Christos S. Savva \\ Cyprus University of Technology
}

November 20, 2014

${ }^{*}$ The authors are grateful for helpful comments from seminar participants at Rady School of Management, University of California San Diego. Aslanidis acknowledges support from the Spanish Ministry of Science and Innovation project grant (Reference $\mathrm{N}^{o}$ ECO2009-11055). Christiansen acknowledges support from CREATES funded by the Danish National Research Foundation (DNRF78) and from the Danish Council for Independent Research, Social Sciences (DFF - 4003-00022).

${ }^{\dagger}$ Universitat Rovira i Virgili, Department d'Economia, CREIP, Avinguda Universitat 1, 43204 Reus, Catalonia, Spain. Email: nektarios.aslanidis@urv.cat.

${ }^{\ddagger}$ CREATES, Department of Economics and Business, School of Business and Social Sciences, Aarhus University, Fuglesangs Alle 4, 8210 Aarhus V, Denmark. Email: CChristiansen@creates.au.dk.

$\S$ Department of Commerce, Finance and Shipping, Cyprus University of Technology, P.O Box 50329, 3603 Limassol, Cyprus. Email: n.lambertides@cut.ac.cy.

TDepartment of Commerce, Finance and Shipping, Cyprus University of Technology, P.O Box 50329, 3603 Limassol, Cyprus. Email: christos.savva@cut.ac.cy. 


\title{
Idiosyncratic Volatility Puzzle: Influence of Macro-Finance Factors
}

\begin{abstract}
In this paper, we scrutinize the cross-sectional relation between idiosyncratic volatility and stock returns. As a novelty, the idiosyncratic volatility is obtained by conditioning upon macro-finance factors as well as upon traditional asset pricing factors. The macro-finance factors are constructed from a large pool of macroeconomic and financial variables. Cleaning for macro-finance effects reverses the puzzling negative relation between returns and idiosyncratic volatility documented previously. Portfolio analysis shows that the effects from macro-finance factors are economically strong. The relation between idiosyncratic volatility and returns does not vary with the NBER business cycles. The empirical results are highly robust.
\end{abstract}

Keywords: Idiosyncratic volatility puzzle; Macro-finance predictors; Factor analysis; Business cycle

JEL Classifications: G12; G14 


\section{Introduction}

An important implication of the Capital Asset Pricing Model (CAPM) is that only systematic risk is priced with idiosyncratic risk being eliminated through diversification. Yet, the empirical evidence suggests that investors are, in general, not well-diversified, e.g. Goetzmann and Kumar (2008). A plausible explanation for this lack of diversification is proposed by the Merton (1987) model where investors cannot perfectly diversify due to market imperfections. As expected, under-diversified investors would demand return compensation for bearing idiosyncratic risk. Nonetheless, the rapidly growing empirical literature testing the idiosyncratic volatility in the cross-section of stocks often documents the so-called idiosyncratic volatility puzzle whereby stocks with high idiosyncratic volatility have low future returns, (e.g. Ang, Hodrick, Xing, and Zhang (2006), Ang, Hodrick, Xing, and Zhang (2009)). Nevertheless, the findings in Bali and Cakici (2008) challenge the robustness of the idiosyncratic volatility puzzle.

In the literature, a variety of economic mechanisms have been proposed to explain the idiosyncratic volatility puzzle. For instance, Fu (2009) argues that the one-month lagged realized idiosyncratic volatility used in Ang, Hodrick, Xing, and Zhang (2006) is a poor predictor of expected idiosyncratic volatility and, therefore, is a poor proxy for idiosyncratic risk. Estimating expected idiosyncratic volatility from an EGARCH model, Fu (2009) documents a positive risk-return trade-off relationship. This paper promotes one explanation of why the idiosyncratic volatility puzzle arises. Another explanation is offered by Huang, Liu, Rhee, and Zhang (2010) that points to an omitted variable bias when stock returns from the previous month are not explicitly controlled for in the risk-return trade-off. The authors show that by including the previous month's return the negative estimate on the lagged 
realized idiosyncratic volatility is attenuated and is close to zero. Further, Chen and Petkova (2012) find that part of the idiosyncratic volatility puzzle can be explained by adding an average variance component when estimating the idiosyncratic volatility. On the other hand, Bali, Nusret, and Whitelaw (2011) test for the significance of extreme positive returns and show that controlling for that the resulting idiosyncratic volatility measure is positively related to subsequent returns.

We offer a novel and attractive solution to the idiosyncratic volatility puzzle by considering the link between volatility and the macro economy. We argue that volatility may not be idiosyncratic before it has been cleaned for effects stemming from macroeconomic and financial (macro-finance hereafter) factors as well as from the traditional effects stemming from the stock market. It is now well established in the literature that there is a link between the macro economy and stock market volatility, e.g., Schwert (1989) and more recently Bloom (2009). Consequently, the macro economy could also be linked to idiosyncratic volatility as increases in macroeconomic uncertainty drives up both systematic and idiosyncratic volatility. Indeed, our results show that allowing for macro-finance factors reverses the puzzling negative relation between returns and idiosyncratic volatility.

We consider the US stock market during the sample period 1971 to 2012 . We adopt a new way of obtaining idiosyncratic volatility that builds upon Boyer, Mitton, and Vorlink (2010) who estimate expected idiosyncratic skewness. The advantage of using this method is that it allows us to account for the influence of additional predictive variables compared to what is done in the previous literature. Furthermore, from a methodological point of view, we follow the recent trend in the finance literature that exploits information obtained from a large amount of macro-finance variables in predicting 
asset returns, e.g., Ludvigson and Ng (2007), Goyal and Welch (2008) and Christiansen, Schmeling, and Schrimpf (2012).

Once we account for the macro-finance factors, the idiosyncratic volatility puzzle is no longer present except at the very short (1-month) horizon. Our results are concerned with volatility horizon not holding period horizon as in the previous literature. We find a strong and positive relation between returns and macro-finance related idiosyncratic volatility in the cross-section. Portfolio analysis documents that the relation between returns and idiosyncratic volatility is economically important. Further, the relation between idiosyncratic volatility and returns is not directly linked to the NBER business cycle. The findings are highly robust; to using different empirical specifications (Brandt, Brav, Graham, and Kumar (2010) and Fu (2009) extended to condition on macro-finance effects), to sub-sample analysis, to including standard cross-sectional asset pricing variables, and to including idiosyncratic skewness which is seen as a proxy for lottery preferences of investors, cf. Bali, Nusret, and Whitelaw (2011).

As long as the common set of macro-finance factors are taken into account when estimating idiosyncratic volatility, the relation between idiosyncratic volatility and returns is similar across estimation methods. This stresses the importance of accounting for macro-finance factors in financial economics.

The remaining part of the paper is organized as follows. First, we introduce the data. Second, we describe the econometric methodology. Third, we present the main empirical findings followed by a number of robustness checks. Finally, we conclude. Various details are delegated to the Appendix. 


\section{Data}

The idiosyncratic volatility regressions in the first step make use of daily data, while the risk-return regressions in the second step are based upon monthly data.

\subsection{Daily Firm Data}

Our sample consists of 22,528 US listed firms during the period March 1971 to December 2012 with data available in the annual Compustat/CRSP Merged Database (excluding financial and utility firms with four-digit SIC codes 4900-4999 and 6000-6999). To reduce the impact of infrequent trading on idiosyncratic volatility estimates, we require a minimum of 15 trading days in a month for which CRSP reports both a daily return and non-zero trading volume. Otherwise, the stock is excluded from the analysis of that month.

In the first step we also use the Fama and French (1993) factors: ${ }^{1}$ The excess return on a broad market portfolio $(M K T)$, the difference between the return on a portfolio of small stocks and the return on a portfolio of large stocks $(S M B)$, and the difference between the return on a portfolio of high book-to-market stocks and the return on a portfolio of low book-to-market stocks $(H M L)$.

\subsection{Macro-Finance Predictors}

We estimate the common factors in a manner similar to Stock and Watson (2002) and Ludvigson and $\mathrm{Ng}(2007)$. Let $X_{t}$ denote a large vector $(N \times 1)$ of macro-finance variables. These variables, are related to the unobserved common factors according to

\footnotetext{
${ }^{1}$ The Fama and French (1993) are freely available from Kenneth French' web page
} 


$$
X_{t}=\Lambda F_{t}+e_{t}
$$

where $\Lambda$ is an $N \times r$ matrix of factor loadings and $F_{t}$ describes the $r$ dimensional vector of unobserved common factors, where $r<<N$. The $N \times 1$ vector $e_{t}$ denotes the purely idiosyncratic errors that are allowed to be serially correlated and weakly correlated across macro-finance variables. ${ }^{2}$ The above equation reflects the fact that the elements of $F_{t}$ represent pervasive forces that drive the common dynamics of $X_{t}$.

We use $N=174$ macro-finance variables similar to Ludvigson and $\mathrm{Ng}$ (2007), for further details consult Table $1 A$ in the Appendix. ${ }^{3}$ The macrofinance variables fall into the following broad groups: Employment and hours; exchange rates and oil prices; housing; interest rates, money and credit; output; prices and inflation; stock market. The number of factors is determined by the information criteria developed in Bai and Ng (2002). The criteria indicates that the factor structure is well described by six common factors, i.e. $r=6$. Taken together, these six factors account for $85 \%$ of the variation of the 174 monthly macro-finance variables. Moreover, to capture any nonlinear effects we also make use of the squares of the factors.

Figure $1 A$ in the Appendix displays the $R$-squared values of the regressions of the 174 individual macro-finance variables against each of the six common factors. We caution that any labeling of the factors is not perfect, because each factor to some degree is influenced by all the variables in the data set and the orthogonalization means that none of them will correspond exactly to a precise economic concept like output or prices, which are nat-

\footnotetext{
${ }^{2}$ This cross-correlation must vanish as $N$ goes to infinity. See Stock and Watson (2002) for a formal discussion of the required restrictions on the cross-correlation of the idiosyncratic errors.

${ }^{3}$ Note however that Ludvigson and $\mathrm{Ng}$ (2007) use quarterly data while our analysis is based on monthly data.
} 
urally correlated. Broadly speaking, the first factor is mostly related to the federal funds rate and various employment variables; the second factor loads primarily on money supply; the third on prices; the fourth on employment indicators; the fifth on housing and prices and inflation. Finally, the sixth factor is most strongly related to output.

\section{$3 \quad$ Econometric Methodology}

The econometric analysis consists of two steps which are described here.

\subsection{Step 1: Idiosyncratic Volatility}

The first step of our modelling procedure is to pin down the idiosyncratic volatility based on the standard and the macro-finance variables. In principle, we would prefer to account for both standard and macro-finance factors at the same time, but this is infeasible due to the fact the standard variables are available at the daily frequency whereas the macro-finance factors are only available at the monthly frequency.

First, we estimate a standard measure of idiosyncratic volatility following Ang, Hodrick, Xing, and Zhang (2006) and Fu (2009). $\tau$ accounts for the daily observations, $t$ accounts for monthly observations, and $i$ keeps track of the company. There is one regression per stock per month. In particular, in every month $t$, the daily excess return of stock $i,\left(R_{i \tau}-r_{\tau}\right)$, is regressed on the daily Fama and French (1993) and Fama and French (1996) factors: the market portfolio $\left(M K T_{\tau}\right)$, the small minus big portfolio $\left(S M B_{\tau}\right)$, and the high minus low portfolio $\left(H M L_{\tau}\right)$ :

$$
R_{i \tau}-r_{\tau}=\alpha_{0 i t}+\alpha_{1 i t} M K T_{\tau}+\alpha_{2 i t} S M B_{\tau}+\alpha_{3 i t} H M L_{\tau}+\varepsilon_{i \tau}
$$


The standard idiosyncratic volatility for stock $i$ in month $t, I V_{i t}$, is the standard deviation of the regression residuals in eq. (2) multiplied by the square root of the number of trading days in that month. The results are robust to using the market model with only two estimated coefficients in place of the Fama and French (1993) specification, more follows at the end of the paper.

Next, we obtain the idiosyncratic volatility based on the macro-finance factors by adopting the analysis in Boyer, Mitton, and Vorlink (2010). ${ }^{4}$ For stock $i$ at time $t$ over horizon $T$, we regress the idiosyncratic volatility on the macro-finance factors and the squared macro-finance factors lagged $t-T$ periods, also accounting for the lagged value of the idiosyncratic volatility:

$$
I V_{i, t}=\beta_{0 t}+\beta_{1 t}^{\prime} F_{t-T}+\beta_{2 t}^{\prime} F_{t-T}^{2}+\beta_{3 t} I V_{i, t-T}+u_{i t}
$$

Then we use the prediction from this regression as the estimate of the macrofinance cleaned idiosyncratic volatility:

$$
\widehat{I V}_{i, t, t+T}=\widehat{\beta}_{0 t}+\widehat{\beta}_{1 t}^{\prime} F_{t}+\widehat{\beta}_{2 t}^{\prime} F_{t}^{2}+\widehat{\beta}_{3 t} I V_{i, t}
$$

Furthermore, to show convincingly that our results are driven by the macro-finance factors and not by other sources we also obtain the idiosyncratic volatility without the macro-finance factors, i.e. where $\beta_{1 t}=\beta_{2 t}=0$ in the above regressions.

We consider short (1-month) and intermediate horizons of 6 to 12 months, $T=\{1,6,12\}$ in detail. Later on we analyze all horizons up to 12 months on a general level.

In Table 1, we report the average coefficient estimates, average standard

\footnotetext{
${ }^{4}$ Boyer, Mitton, and Vorlink (2010) estimate the expected idiosyncratic skewness using other types of independent variables than macro-finance factors.
} 
errors, average $t$-statistics, and average adjusted $R$-squared values from estimating eq (3) with and without macro-finance factors. The results show that across different horizons there is a substantial increase in model fit induced by including macro-finance factors. Thus, the model fit is not driven by autoregressive behavior. Factor 1, Factor 3, Factor 5, and Factor 6 as well as Factor 5 squared and Factor 6 squared are statistically significant. Furthermore, the distribution of the coefficient estimates, standard errors and $R$-squared values suggest that the results are not driven by specific firms or outliers (results not shown).

[Insert Table 1]

\subsection{Step 2: Idiosyncratic Volatility and Stock Returns}

The second step consists of cross-sectional regressions of individual stocks, similar in spirit to Fama and MacBeth (1973) regressions. Here we use the idiosyncratic volatility based on the macro-finance factors for a given stock to predict its return. In addition, we control for other relevant variables. Specifically, for each month $t$ we run the following cross-sectional regression:

$$
R_{i, t}=\gamma_{0 t}+\gamma_{1 t} \widehat{I V}_{i, t, t+T}+\gamma_{2 t}^{\prime} Z_{i, t}+\varepsilon_{i, t}
$$

where $i=1, \ldots, N_{t}$ keeps track of the stock identity, $N_{t}$ denotes the total number of stocks in month $t$, and $T$ is the volatility horizon. $R_{i, t}$ is the realized return on stock $i$ in month $t$. $Z_{i, t}$ is a vector of various firm characteristics that are known to explain cross-sectional returns such as the estimate of stock $i$ 's beta in month $t, B e t a_{i, t}$, the $\log$ of stock $i$ 's market capitalization at the end of month $t, \ln (M E)_{i, t}$, the $\log$ of stock $i$ 's book-to-market ratio as of end of month $t$ based on the last fiscal year's information, $\ln (b / m)_{i, t}$, the $\log$ 
of stock $i$ 's average share turnover in the past 36 months, $\ln (T U R N)_{i, t}$, the coefficient of variation of the previous 36 months' turnover, $\ln (C V T U R N)_{i, t}$, stock $i$ 's compound gross return from month $t-7$ to $t-2, \operatorname{Ret}(-2,-7)$, as a proxy for momentum. We do not explicitly include a proxy for reversals, say $\operatorname{Ret}(-1)$, in our regressors list as in Huang, Liu, Rhee, and Zhang (2010), because the two measures $\operatorname{Ret}(-2,-7)$ and $\operatorname{Ret}(-1)$ are supposedly highly correlated. ${ }^{5}$

From eq. (5) we obtain coefficient estimates for each month, $\widehat{\gamma}_{j t}$ for $j=0,1,2$. Then, the final coefficient estimates, $\widehat{\gamma}_{j}$ are the averages across month-specific estimates, respectively with standard errors based on Newey and West (1987). The under-diversification hypothesis and the idiosyncratic volatility puzzle are tested as alternatives to the null hypothesis regarding the gamma coefficient $H_{0}: \gamma_{1}=0$. That is, the null hypothesis is that the idiosyncratic volatility is irrelevant and hence not priced.

$$
\begin{aligned}
& H_{0}: \gamma_{1}=0 \text { (irrelevance) } \\
& H_{1}: \gamma_{1}>0 \text { (under-diversification) } \\
& H_{2}: \gamma_{1}<0 \text { (IV puzzle) }
\end{aligned}
$$

When $\gamma_{1}$ is positive, the investor is compensated for bearing idiosyncratic risk. On the other hand, a negative $\gamma_{1}$ is in accordance with the idiosyncratic volatility puzzle from the previous literature.

\footnotetext{
${ }^{5}$ There is one such correlation coefficient per company per month.
} 


\section{Results: Idiosyncratic Volatility and Re- turns}

In this section, we show the main results. Table 2 holds the regression results for various specifications for $T=1,6,12$.

[Insert Table 2]

Panel $A$ summarizes the results with various firm characteristics included, but without the idiosyncratic volatility. Note that the sign of the coefficient estimates from the various firm characteristics does not change in any of the subsequent models. Thus, these firm characteristics are truly control variables. These signs are generally consistent with previous studies in the literature.

Panel $B$ shows the results when the idiosyncratic volatility is estimated conditioning on the macro-finance factors. Note, by using the idiosyncratic volatility based on the short (1-month) horizon, the relation is negative and significant, thus in accordance with the idiosyncratic volatility puzzle. More importantly, the results at the intermediate horizon (6 and 12 months) show that the risk-return trade-off turns positive and significant at the $1 \%$ level, a result which supports the under-diversification hypothesis. The average gamma coefficient of around 0.14 is close to the estimates in $\mathrm{Fu}$ (2009), which lends further support to our findings.

To show that our results are driven by the macro-finance factors and not by other sources we consider the case without conditioning upon macrofinance factors. Panel $C$ holds the results. Here, the relation between idiosyncratic volatility and returns is strongly negative implying that investors are not compensated for taking on additional risk, rather the opposite is true, 
i.e. the idiosyncratic volatility puzzle. The findings without macro-finance factors are consistent with the findings in Ang, Hodrick, Xing, and Zhang (2006) and Ang, Hodrick, Xing, and Zhang (2009).

We investigate if the results are robust to including firm specific control variables in addition to the macro-finance factors when estimating the idiosyncratic volatility in eq (3). For this we use the firm specific variables that are also used in eq (5). The cross-sectional regressions from eq. (5) are qualitatively similar (not tabulated). Specifically, with macro-finance factors the gamma coefficient is significantly positive while without macro-finance factors it is significantly negative.

We investigate further variations across all volatility horizons, $T=1, . .12$ (not tabulated). The results for horizons of 2-months and up are all similar, namely that the gamma coefficients are all significantly positive and of about the same size. Only for the 1-month horizon is the gamma coefficient significantly negative. It is worth noting that whereas the current paper considers volatility horizons, the previous literature considers holding period returns, so the results are not directly comparable. More specifically, at the aggregate market level of conditional volatility and conditional return , Harrison and Zhang (1999), Lundblad (2007), and Bandi and Perron (2008) uncover a significantly positive risk-return trade-off only at very long holding period horizons, which is nonexistent at short holding periods such as one month.

\section{Business Cycle Variations}

In this section we document that the positive relation between idiosyncratic volatility and returns when taking macro-finance factors into account is truly caused by conditioning appropriately upon the macro-finance factors and 
not by other excluded economic variables. For this purpose we introduce the NBER business cycle indicator that has previously been connected to variations in the risk-return trade-off, cf. Lustig and Verdelhan (2012) and Nyberg (2012).

We investigate the business cycle variation in the gamma coefficients from the cross-sectional regressions in eq. (5) by running time series regressions. More specifically, we consider as the dependent variable the gamma coefficients $\gamma_{1 t}$ from eq. (5) for the models with and without macro-finance factors using the idiosyncratic volatility at 6 and 12 month horizons. Figure 1 shows the time series of these gamma coefficients at the 6 month horizon. The independent variables are the NBER business cycle indicator, and the six macro-finance factors and their squares. ${ }^{6}$

[Insert Figure 1]

[Insert Table 3]

Table 3 holds the results. When conditioning upon macro-finance factors, the gamma coefficients are related to the macro-finance factors. The NBER business cycle indicator is always insignificant, so the business cycle indicator is not in itself important. This is also evident from Figure 1. Without macrofinance factors there is little evidence of systematic time-variation across the business cycles. This is also strongly evident from Figure 1.

Thus, the fact that it is important to account for macro-finance factors when estimating idiosyncratic volatility is not caused by ignoring variations across the business cycle. This may be in contrast to the findings regarding the aggregate market conditional volatility and conditional returns in Lustig

\footnotetext{
${ }^{6}$ The results are robust to including the Economic Policy Uncertainty Index of Baker, Bloom, and Davis (2013) as it is insignificant. The index is freely available at www. policyuncertainty.com.
} 
and Verdelhan (2012) and Nyberg (2012) who show that Sharpe ratios are higher in recessions that in expansions. Nevertheless, it is still in accordance with the findings of Ghysels, Plazzi, and Valkanov (2013) regarding the aggregate market conditional volatility who show that the Sharpe ratios are related to flight-to-safety variation.

\section{Portfolios Sorted on Idiosyncratic Volatil- ity}

In this section, we further examine the economic importance of the macrofinance factors for the relation between the idiosyncratic volatility and returns by using portfolio analysis in a manner similar to Ang, Hodrick, Xing, and Zhang (2006), Ang, Hodrick, Xing, and Zhang (2009), and Fu (2009).

\section{[Insert Table 4]}

In Table 4, we report equal-weighted average monthly returns of quintile portfolios and differences between the extreme portfolios. In constructing these portfolio returns we cross-sectionally sort each stock into five equalsized groups based on the idiosyncratic volatility, $\widehat{I V}_{i, t, t+T}$. Panel $A$ reports portfolio returns for the idiosyncratic volatility estimated over 6 months (the portfolio formation month is $t+6$ ), while Panel $B$ reports results for the idiosyncratic volatility estimated over 12 months (the portfolio formation month is $t+12$ ). Further, we compute the risk adjusted (equally-weighted) average return over the next 6 months (holding period is up to 6 months). We also report portfolio hedge returns as the difference in the average portfolio returns between the extreme quintiles (High minus Low volatility). Test statistics are reported based on time series variation in these portfolio hedge 
returns. This approach assumes monthly rebalancing and ignores the impact of transaction costs. For robustness we also report the spreads in the alphas of the hedged portfolio (regressed on Fama and French (1993) factors) along with the corresponding Newey and West (1987) $t$-statistics. ${ }^{7}$

Across these alternative volatility measures, there is an economically significant predictive association between expected volatility and average future returns. Average returns increase monotonically from the first quintile to the fifth quintile. The largest increase in average returns occurs between fourth and fifth quintiles. For example, the $0.40 \%$ monthly portfolio hedge differential between the High and Low portfolios (quintiles) sorted on idiosyncratic volatility over the next 6 months for explaining simultaneous returns (RET0) amounts to an annualized $4.9 \%$ return differential. This is both statistically and economically significant. The Fama and MacBeth (1973) (FM) test statistic of 2.38 is equivalent to a monthly Sharpe ratio of 0.11 ; cf. Lewellen (2010) for a mapping of FM $t$-statistics to Sharpe ratios. Across both volatility measures with hedge portfolio returns estimated for 0-6 months ahead (RET0 - RET6) in Panels $A$ and $B$, the monthly Sharpe ratio ranges from 0.06 to 0.11 . These are economically significant, cf. Lewellen (2010). All in all, the average risk-adjusted return differences between the extreme portfolios are positive and significant with very few exceptions.

To get a clearer picture of the role of the macro-finance factors, Panels $C$ and $D$ report the corresponding results when idiosyncratic volatility is obtained without appropriately conditioning the macro-finance factors. In this sorting, the average return on the highest idiosyncratic volatility portfolio is lower than the average return on the other four portfolios, though the difference is not statistically significant. These analyses provide convincing

\footnotetext{
${ }^{7}$ The results are even stronger if we use the Carhart (1997) 4 -factor model in place of the Fama and French (1993) model.
} 
evidence that only when expected idiosyncratic volatility is estimated using the macro-finance factors there is a significant positive relation between expected idiosyncratic volatility and portfolio returns.

\section{Robustness Analysis}

Here we show that our results are highly robust to a number of alternative specifications. The robustness confirms the usefulness of our specification. The clear conclusion is that by conditioning upon macro-finance factors when estimating the idiosyncratic volatility we are able to offer a new solution to the idiosyncratic volatility puzzle. The standard idiosyncratic volatility used in previous research seems to be inadequate because it does not account for effects from macro-finance factors.

\subsection{Sub-Sample Analysis}

We conduct sub-sample analysis because Campbell, Lettau, Malkiel, and $\mathrm{Xu}$ (2001) document a positive trend in idiosyncratic volatility during their sample period (1962-1997). This could imply that there is time variation in the relation between idiosyncratic volatility and future returns. To check this, we investigate the 1971-1989 period and the 1990-2012 period thereby using 1990 as the splitting point. Table 5 holds the sub-sample cross-sectional regressions from eq. (5). The relation between idiosyncratic volatility and stock returns appears identical across the two sub-samples and the results for the two sub-periods are similar to those for the entire sample period contained in Table 2. Thus, our results are not caused by sub-sample variations or choice of an updated or unusual sample period.

[Insert Table 5] 


\subsection{Skewness Results}

We add the idiosyncratic skewness as a proxy for lottery preferences of investors to the regressions in eq. (5) where the idiosyncratic skewness is estimated as in Boyer, Mitton, and Vorlink (2010). The lottery preferences interpretation stems from Bali, Nusret, and Whitelaw (2011). The results are tabulated in Table 6 for both the entire sample and the sub-samples. The idiosyncratic skewness is significant in all specifications. There is a negative relation such that the larger the idiosyncratic skewness is, the smaller is the expected return. This is similar to the findings to Boyer, Mitton, and Vorlink (2010) and Bali, Nusret, and Whitelaw (2011).

Even though, the idiosyncratic skewness enters significantly into the relation between idiosyncratic volatility and future returns it does not qualitatively change the impact of the other variables including the idiosyncratic volatility. Thus, the relation is invariant to including idiosyncratic skewness.

[Insert Table 6]

\subsection{Alternative Idiosyncratic Volatility Measures}

We investigate if the results are robust to variations in the way we estimate the idiosyncratic volatility. We now try the Brandt, Brav, Graham, and Kumar (2010) method extended to condition upon macro-finance factors into account. This implies using the market model to estimate the idiosyncratic volatility, that is the same as above but setting $\alpha_{2}=\alpha_{3}=0$ in eq. (2). In Table 7 we show the cross-section regressions. The results across horizons are qualitatively similar to the results in Table 2 .

[Insert Table 7] 
We also use the EGARCH specification of Fu (2009) extended to account for the macro-finance factors. Again, the cross-sectional results shown in Table 8 do not differ qualitatively from those in Table 2. Note that the Brandt, Brav, Graham, and Kumar (2010) and Fu (2009) idiosyncratic volatility estimates are strongly correlated (correlation coefficient of 99\%), so it is not surprising that the two sets of results are similar.

Overall, the results here show that as long as we take the common set of macro-finance factors into account when estimating the idiosyncratic volatility we find similar results. Thus, the specific estimation procedure for the idiosyncratic volatility is not overly important, as long as, the effects from macro-finance factors are taken into account. This underscores the importance of allowing for macro-finance factors when estimating the idiosyncratic volatility for the stock market.

\section{Conclusion}

In this paper, we offer a novel and attractive solution to the idiosyncratic volatility puzzle by considering the link between idiosyncratic volatility and the macro economy. We provide a new measure of the idiosyncratic volatility that conditions upon macro-finance factors as well as upon the standard asset pricing variables. The macro-finance factors are constructed from a large pool of macroeconomic and financial variables. Once we account for the macro-finance effects in the idiosyncratic volatility we find that the idiosyncratic volatility puzzle disappears and that the relation between idiosyncratic volatility and stock returns is significantly and strongly positive. Portfolio analysis documents that the positive relation is also economically important. We uncover only few variations across the volatility horizon, except that the 
idiosyncratic volatility puzzle remains only at the short very horizon. We document that the relation between idiosyncratic volatility and returns is not related to the NBER business cycles. The empirical results are robust to different measures of the idiosyncratic volatility, to different sub-samples, and to the inclusion of standard asset pricing variables and the idiosyncratic skewness. In summary, our results show that it is essential to condition on macro-finance factors when estimating idiosyncratic volatility, but that it is not overly important how this is done.

In future research it would be of interest to investigate further if accounting for macro-finance factors is able to solve the idiosyncratic volatility puzzle at other financial markets besides the US stock market such as European stock markets.

\section{References}

Ang, A., R. J. Hodrick, Y. Xing, and X. Zhang (2006): "The Crosssection of Volatility and Expected Returns," Journal of Finance, 61, 259-299.

(2009): "High Idiosyncratic Volatility and Low Returns: International and Further US Evidence," Journal of Financial Economics, 91(1), $1-23$.

BAI, J., AND S. NG (2002): "Determining the Number of Factors in Approximate Factor Models," Econometrica, 70(1), 135-172.

Baker, S. R., N. Bloom, and S. J. Davis (2013): "Measuring Economic Policy Uncertainty," Working Paper, SSRN. 
BALI, T., And N. CAKICI (2008): "Idiosyncratic Volatility and the Cross Section of Expected Returns," Journal of Financial and Quantitative Analysis, 43(1), 29-58.

Bali, T., C. Nusret, and R. Whitelaw (2011): "Maxing Out: Stocks as Lotteries and the Cross-Section of Expected Returns," Journal of Financial Econonomics, 99, 427-446.

Bandi, F. M., and B. Perron (2008): "Long-Run Risk-Return TradeOffs," Journal of Econometrics, 143, 349-374.

Bloom, N. (2009): "The Impact of Uncertainty Shocks," Econometrica, $77(3), 623-685$.

Boyer, B., T. Mitton, and K. Vorlink (2010): "Expected Idiosyncratic Skewness," Review of Financial Studies, 23, 169-202.

Brandt, M. W., A. Brav, J. R. Graham, and A. Kumar (2010): "The Idiosyncratic Volatility Puzzle: Time Trend or Speculative Episodes," Review of Financial Studies, 23, 863-899.

Campbell, J. Y., M. Lettau, B. G. Malkiel, and Y. Xu (2001): "Have Individual Stocks Become More Volatile? An Empirical Exploration of Idiosyncratic Risk," Journal of Finance, 56, 1-43.

Carhart, M. M. (1997): "On Persistence in Mutual Fund Performance," Journal of Finance, 52(1), 57-82.

Chen, Z., and P. Petkova (2012): "Does Idiosyncratic Volatility Proxy for Risk Exposure," Review of Financial Studies, 25(9), 2745-2787. 
Christiansen, C., M. Schmeling, and A. Schrimpf (2012): "A Comprehensive Look at Financial Volatility Prediction by Economic Variables," Journal of Applied Econometrics, 27, 956-977.

Fama, and French (1993): "Common Risk Factors in the Returns on Stocks and Bonds," Journal of Financial Economics, 33, 3-56.

_ (1996): "Multifactor Explanations of Asset Pricing Anomalies," Journal of Finance, 52, 55-84.

Fama, and MacBeth (1973): "Risk, Return, and Equilibrium: Empirical Tests," Journal of Political Economy, 71, 607-636.

Fu, F. (2009): "Idiosyncratic Risk and the Cross-Section of Expected Returns," Journal of Financial Ecnomics, 91, 24-37.

Ghysels, E., A. Plazzi, and R. Valkanov (2013): "The Risk-Return Relationship and Financial Crises," Working Paper, UNC.

Goetzmann, W., and A. Kumar (2008): "Equity Portfolio Diversification," Review of Finance, 12(3), 433-463.

Goyal, A., and I. Welch (2008): "A Comprehensive Look at The Empirical Performance of Equity Premium Prediction," The Review of Financial Studies, 21(4), 1455-1508.

Harrison, P., and H. Zhang (1999): "An Investigation of the Risk and Return Relation at Long Horizons," Journal of Economics and Statistics, 81, 399-408.

Huang, W., Q. Liu, S. Rhee, and L. Zhang (2010): "Return Reversals, Idiosyncratic Volatility, and Expected Returns," Review of Financial Studies, 23(1), 147-168. 
Lewellen, J. (2010): "Accounting Anomalies and Fundamental Analysis: An Alternative View," Journal of Accounting and Economics, 50, 455-466.

Ludvigson, S. C., And S. NG (2007): "The Empirical Risk-Return Relation: A Factor Analysis Approach," Journal of Financial Economics, $83(1), 171-222$.

Lundblad, C. (2007): "The Risk Return Tradeoff in the Long Run: 1836âĂŞ2003," Journal of Financial Economics, 85, 123-150.

Lustig, H., And A. Verdelhan (2012): "Business Cycle Variation in the Risk-Return Trade-Off," Journal of Monetary Economics, 59, 35-49.

Merton, R. C. (1987): "Presidential Address: A Simple Model of Capital Market Equilibrium with Incomplete Information," Journal of Finance, $42,483-510$.

Newey, W. K., and K. D. West (1987): "A Simple, Positive SemiDefinite, Heteroskedasticity and Autocorrelation Consistent Covariance Matrix," Econometrica, 55(3), 703-708.

Nyberg, H. (2012): "Risk-Return Tradeoff in U.S. Stock Returns over the Business Cycle," Journal of Financial and Quantitative Analysis, 47(1), $137-158$.

Schwert, G. W. (1989): "Why Does Stock Market Volatility Change over Time?," Journal of Finance, 44, 1115-1153.

Stock, J. H., and M. W. Watson (2002): "Macroeconomic Forecasting Using Diffusion Indexes," Journal of Business and Economic Statistics, 20(2), 147-162. 
Figure 1: Time Series of Gamma Coefficients for $\mathrm{T}=6$

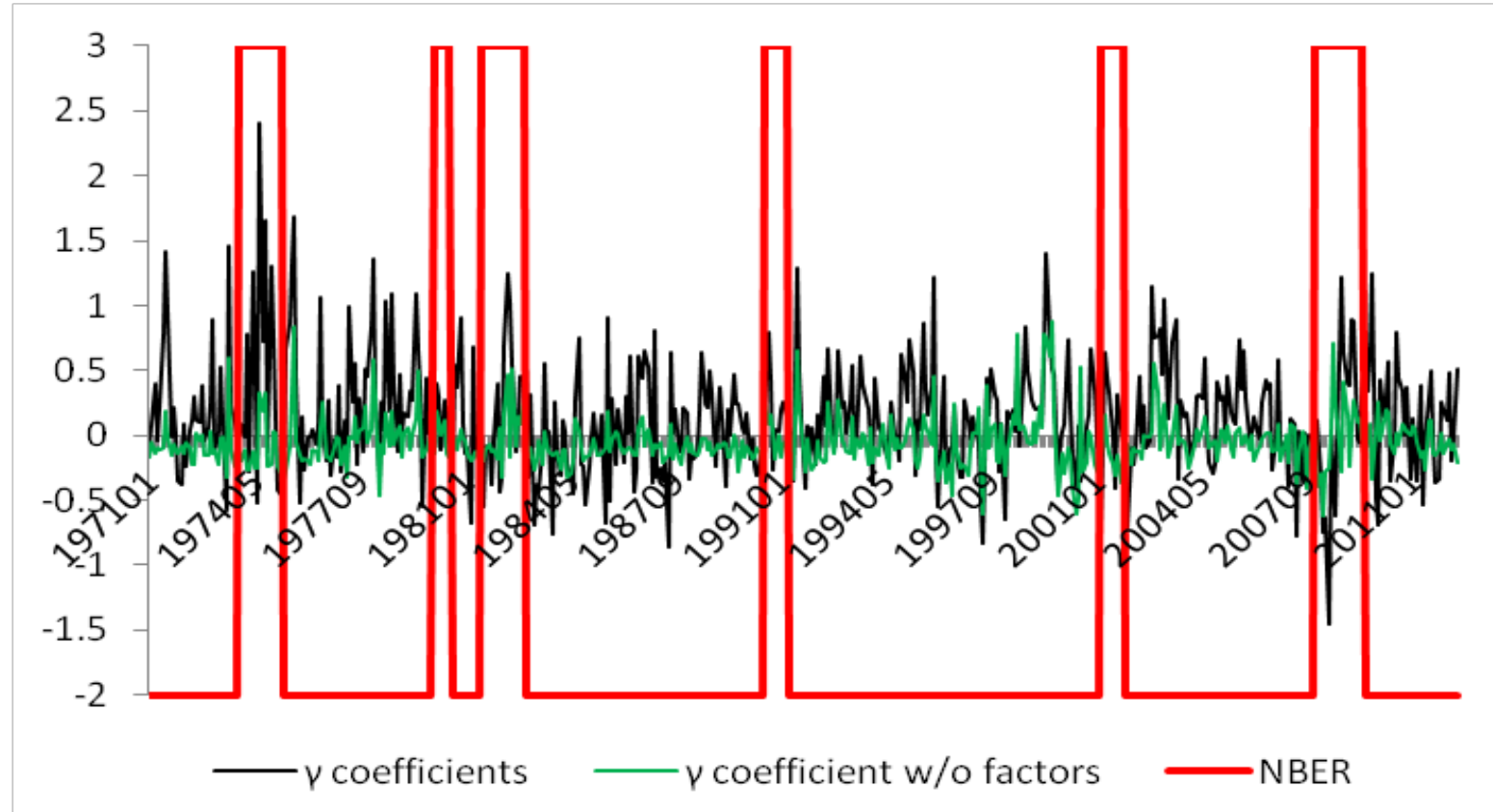

Notes: The figure shows the estimated gamma coefficients for horizon $\mathrm{T}=6$ for the

idiosyncratic volatility that is conditioned on the macro-finance factors (black line) and that is not (green line). The red line symbolizes NBER recessions (different scaling). 
Table 1: Idiosyncratic Volatility Regressions

Panel A: With Macro-Finance Factors

\begin{tabular}{|c|c|c|c|c|c|c|c|c|c|c|c|c|c|c|c|c|}
\hline $\mathrm{T}$ & & cons & f1 & $\mathrm{f} 2$ & f3 & $\mathrm{f4}$ & $\mathrm{f5}$ & f6 & $\mathrm{f} 1^{2}$ & $f 2^{2}$ & $f 3^{2}$ & $\mathrm{f} 4^{2}$ & $f 5^{2}$ & $f 6^{2}$ & $\mathrm{IV}_{\mathrm{t}-\mathrm{T}}$ & $\operatorname{Adj} R^{2}$ \\
\hline \multirow[t]{3}{*}{$\overline{1}$} & Av. Coef. & 15.36 & -0.18 & 0.13 & 0.01 & 0.00 & 0.04 & 0.07 & 0.05 & 0.02 & 0.01 & 0.01 & -0.01 & 0.01 & 0.27 & $57.7 \%$ \\
\hline & Stdev & 10.18 & 0.03 & 0.09 & 0.00 & 0.00 & 0.01 & 0.03 & 0.06 & 0.01 & 0.01 & 0.01 & 0.00 & 0.00 & 0.08 & \\
\hline & t-statistic & 1.51 & -6.39 & 1.44 & 3.62 & 0.01 & 3.08 & 2.15 & 0.76 & 1.25 & 1.29 & 1.18 & -3.11 & 2.15 & 3.56 & \\
\hline \multirow[t]{3}{*}{$\overline{6}$} & Av. Coef. & 15.37 & -0.17 & 0.13 & 0.02 & 0.00 & 0.04 & 0.06 & 0.05 & 0.02 & 0.01 & 0.01 & -0.01 & 0.01 & 0.13 & $52.3 \%$ \\
\hline & Stdev & 10.08 & 0.03 & 0.09 & 0.00 & 0.00 & 0.01 & 0.03 & 0.06 & 0.01 & 0.01 & 0.01 & 0.00 & 0.00 & 0.04 & \\
\hline & t-statistic & 1.53 & -5.98 & 1.43 & 3.90 & -0.58 & 2.99 & 2.22 & 0.76 & 1.25 & 1.29 & 1.17 & -3.28 & 2.14 & 3.15 & \\
\hline \multirow[t]{3}{*}{$\overline{12}$} & Av. Coef. & 15.36 & -0.17 & 0.13 & 0.02 & 0.00 & 0.04 & 0.06 & 0.05 & 0.02 & 0.01 & 0.01 & -0.01 & 0.01 & 0.11 & $54.2 \%$ \\
\hline & Stdev & 9.96 & 0.03 & 0.09 & 0.01 & 0.00 & 0.01 & 0.03 & 0.06 & 0.01 & 0.01 & 0.01 & 0.00 & 0.00 & 0.04 & \\
\hline & t-statistic & 1.54 & -5.95 & 1.43 & 3.81 & -0.78 & 2.97 & 2.25 & 0.76 & 1.24 & 1.30 & 1.16 & -3.34 & 2.14 & 3.04 & \\
\hline
\end{tabular}

Panel B: No Macro-Finance Factors

\begin{tabular}{llrrr}
\hline $\mathrm{T}$ & & cons & $\mathrm{IV}_{\mathrm{t}-\mathrm{T}}$ & Adj R $^{2}$ \\
\hline 1 & Av. Coef. & 9.30 & 0.38 & $42.0 \%$ \\
& Stdev & 5.97 & 0.10 & \\
& t-statistic & 1.56 & 3.84 & \\
\hline 6 & Av. Coef. & 11.68 & 0.22 & $39.7 \%$ \\
& Stdev & 7.16 & 0.07 & \\
& t-statistic & 1.63 & 3.34 & \\
\hline 12 & Av. Coef. & 12.40 & 0.15 & $36.7 \%$ \\
& Stdev & 7.35 & 0.05 & \\
& t-statistic & 1.69 & 3.16 & \\
\hline
\end{tabular}

Notes: The table shows the average coefficients, average standard deviations, average t-statistics, and average adjusted R-squared values from estimating eq. (3). 
Table 2: Cross-Sectional Risk-Return Regressions

Panel A: No Idiosyncratic Volatility

\begin{tabular}{|c|c|c|c|c|c|c|c|c|}
\hline cons & beta & $\ln (\mathrm{ME})$ & $\ln (\mathrm{b} / \mathrm{m})$ & $\operatorname{Ret}(-2,-7)$ & Ln(TURN $)$ & Ln(CVTURN $)$ & $\mathrm{IV}(\mathrm{T})$ & $\operatorname{Adj~} R^{2}$ \\
\hline 1.47 & 0.09 & -0.19 & 0.10 & 0.44 & -0.15 & -0.51 & & $4.2 \%$ \\
\hline$(4.16)^{* * *}$ & $(0.91)$ & $(-4.63)^{* * *}$ & $(2.55)^{* *}$ & $(1.72)^{*}$ & $(-2.09)^{* *}$ & $(-7 .)^{* * *}$ & & \\
\hline
\end{tabular}

Panel B: With Macro-Finance Factors

\begin{tabular}{|c|c|c|c|c|c|c|c|c|c|}
\hline $\mathrm{T}$ & cons & beta & $\ln (\mathrm{ME})$ & $\ln (\mathrm{b} / \mathrm{m})$ & $\operatorname{Ret}(-2,-7)$ & Ln(TURN) & Ln(CVTURN) & $\mathrm{IV}(\mathrm{T})$ & $\operatorname{Adj} R^{2}$ \\
\hline \multirow[t]{2}{*}{1} & 2.62 & 0.16 & -0.30 & 0.07 & 0.34 & -0.07 & -0.47 & -5.13 & $4.9 \%$ \\
\hline & $(8.38)^{* * *}$ & $(2.04)^{* *}$ & $(-8.36)^{* * *}$ & $(2.03)^{* *}$ & $(1.34)$ & $(-1.15)$ & $(-7.02)^{* * *}$ & $(-5.19) * * *$ & \\
\hline \multirow[t]{2}{*}{6} & 1.12 & 0.05 & -0.16 & 0.10 & 0.52 & -0.19 & -0.53 & 0.15 & $4.7 \%$ \\
\hline & $(3.58)^{* * *}$ & $(0.57)$ & $(-4.1) * * *$ & $(2.84)^{* * *}$ & $(2.12)^{* *}$ & $(-2.86) * * *$ & $(-7.35)^{* * *}$ & $(6.06)^{* * *}$ & \\
\hline \multirow[t]{2}{*}{12} & 1.12 & 0.05 & -0.16 & 0.10 & 0.52 & -0.19 & -0.53 & 0.14 & $4.7 \%$ \\
\hline & $(3.58)^{* * *}$ & $(0.58)$ & $(-4.11)^{* * *}$ & $(2.85)^{* * *}$ & $(2.12)^{* *}$ & $(-2.84) * * *$ & $(-7.35)^{* * *}$ & $(5.99)^{* * *}$ & \\
\hline
\end{tabular}

Panel C: No Macro-Finance Factors

\begin{tabular}{|c|c|c|c|c|c|c|c|c|c|}
\hline $\mathrm{T}$ & cons & beta & $\ln (\mathrm{ME})$ & $\ln (\mathrm{b} / \mathrm{m})$ & $\operatorname{Ret}(-2,-7)$ & Ln(TURN) & Ln(CVTURN) & $\mathrm{IV}(\mathrm{T})$ & $\operatorname{Adj} R^{2}$ \\
\hline \multirow[t]{2}{*}{$\overline{1}$} & 2.77 & 0.18 & -0.31 & 0.07 & 0.32 & -0.06 & -0.47 & -5.76 & $4.9 \%$ \\
\hline & $(9.1)^{* * *}$ & $(2.2)^{* *}$ & $(-8.77)^{* * *}$ & $(1.91)^{*}$ & $(1.27)$ & $(-1)$. & $(-6.9) * * *$ & $(-5.97) * * *$ & \\
\hline \multirow[t]{2}{*}{6} & 2.71 & 0.18 & -0.30 & 0.07 & 0.32 & -0.07 & -0.46 & -5.48 & $5.0 \%$ \\
\hline & $(8.85)^{* * *}$ & $(2.3)^{* *}$ & $(-8.81)^{* * *}$ & $(1.96)^{* *}$ & $(1.31)$ & $(-1.08)$ & $(-6.95)^{* * *}$ & $(-5.23) * * *$ & \\
\hline \multirow[t]{2}{*}{12} & 2.73 & 0.18 & -0.30 & 0.06 & 0.32 & -0.07 & -0.46 & -5.75 & $5.0 \%$ \\
\hline & $(9.01)^{* * *}$ & $(2.24)^{* *}$ & $(-8.84)^{* * *}$ & $(1.86)^{*}$ & $(1.28)$ & $(-1.09)$ & $(-6.87)^{* * *}$ & $(-5.29)^{* * *}$ & \\
\hline
\end{tabular}

Notes: The table reports the average coefficients and average t-statistics from the cross-sectional regressions in eq. (5). IV(T) is the T-monthahead idiosyncratic volatility from eq. (4), beta is estimated using the two-step procedure described by Fama and French (1992), ln(ME) is the $\log$ of market capitalization, $\mathrm{b} / \mathrm{m}$ is the $\log$ of book-to-market ratio, $\ln (\mathrm{TURN})$ is the average share turnover in the past 36 months,

$\ln$ (CVTURN) is the coefficient of variation of the previous 36 months' turnover, and Ret(-2,-7) is the compound gross return from month t-7 to $\mathrm{t}-2 . * / * * / * * *$ indicates that the parameter is significant at the $10 \% / 5 \% / 1 \%$ level. 
Table 3: Time-Variation in Gamma Coefficients

Panel A: With Macro-Finance Factors

\begin{tabular}{|c|c|c|c|c|c|c|c|c|c|c|c|c|c|c|c|}
\hline $\mathrm{T}$ & const & NBER & $\mathrm{f}_{1}$ & $\mathrm{f}_{2}$ & $\mathrm{f}_{3}$ & $\mathrm{f}_{4}$ & $\mathrm{f}_{5}$ & $\mathrm{f}_{6}$ & $\mathrm{f}_{1}^{2}$ & $\mathrm{f}_{2}^{2}$ & $\mathrm{f}_{3}^{2}$ & $\mathrm{f}_{4}^{2}$ & $f_{5}^{2}$ & $\mathrm{f}_{6}{ }^{2}$ & $\operatorname{Adj~} R^{2}$ \\
\hline 6 & $0.1^{* * *}$ & 0.1 & & & & & & & & & & & & & $0.0 \%$ \\
\hline 6 & $0.1^{* * *}$ & -0.1 & $1.4^{* * *}$ & $1.3^{* * *}$ & 0.1 & 0.4 & $-1.2 * *$ & 0.5 & -2.7 & 3.6 & 1.8 & 1.6 & 11.6 ** & $-3.6 *$ & $6.0 \%$ \\
\hline 12 & $0.1 * * *$ & 0.1 & & & & & & & & & & & & & $0.0 \%$ \\
\hline 12 & $0.1^{* * *}$ & -0.1 & $1.3^{* * *}$ & $1.3 * *$ & 0.0 & 0.4 & $-1.2 * * *$ & 0.5 & -2.1 & 3.7 & 2.5 & 0.5 & $11.4 * * *$ & -4.3 & $6.0 \%$ \\
\hline
\end{tabular}

Panel B: No Macro-Finance Factors

\begin{tabular}{|c|c|c|c|c|c|c|c|c|c|c|c|c|c|c|c|}
\hline $\mathrm{T}$ & const & NBER & $\mathrm{f}_{1}$ & $\mathrm{f}_{2}$ & $\mathrm{f}_{3}$ & $\mathrm{f}_{4}$ & $\mathrm{f}_{5}$ & $\mathrm{f}_{6}$ & $\mathrm{f}_{1}^{2}$ & $\mathrm{f}_{2}^{2}$ & $\mathrm{f}_{3}^{2}$ & $\mathrm{f}_{4}^{2}$ & $\mathrm{f}_{5}^{2}$ & $\mathrm{f}_{6}^{2}$ & $\overline{A d j} R^{2}$ \\
\hline 6 & $-5.7 * * *$ & 1.7 & & & & & & & & & & & & & $0.0 \%$ \\
\hline 6 & $-3.8 * * *$ & -1.8 & 22.2 & $53.9 *$ & 22.7 & -21.2 & 6.5 & -8.1 & -12.9 & 87.9 & -338 & -30.5 & 154 & $-523 *$ & $3.0 \%$ \\
\hline 12 & $-6.0 * * *$ & 1.9 & & & & & & & & & & & & & $0.0 \%$ \\
\hline 12 & $-5.0 * * *$ & -3.7 & 22.5 & $54.9 *$ & 22.9 & -9.9 & 5.5 & -15.5 & -15.5 & 329 & -169 & -19.8 & 207 & -391 & $3.0 \%$ \\
\hline
\end{tabular}

Notes: The tables shows the estimated coefficients from regressing the gamma parameters on the NBER recession indicator, and macro-finance factors and their squared values. $* / * * / * *$ indicates that the parameter is significant at the 10\%/5\%/1\% level. 
Table 4: Portfolios Formed on Idiosyncratic Volatility

Panel A: With Macro-Finance Factors, $\mathrm{T}=6$

\begin{tabular}{lccccccc}
\hline & RET0 & RET1 & RET2 & RET3 & RET4 & RET5 & RET6 \\
\hline Bottom & 1.17 & 1.20 & 1.24 & 1.27 & 1.24 & 1.27 & 1.25 \\
2 & 1.25 & 1.28 & 1.25 & 1.26 & 1.29 & 1.28 & 1.29 \\
3 & 1.27 & 1.29 & 1.28 & 1.30 & 1.30 & 1.35 & 1.28 \\
4 & 1.25 & 1.35 & 1.33 & 1.33 & 1.37 & 1.34 & 1.36 \\
Top & 1.56 & 1.53 & 1.52 & 1.51 & 1.54 & 1.59 & 1.58 \\
\hline Hedge (top-bottom) & 0.40 & 0.34 & 0.28 & 0.23 & 0.30 & 0.33 & 0.32 \\
FM t-stat & 2.38 & 2.00 & 1.68 & 1.42 & 1.81 & 1.94 & 1.96 \\
Sharpe & 0.11 & 0.09 & 0.08 & 0.06 & 0.08 & 0.09 & 0.09 \\
Alpha-hedge & 0.16 & 0.29 & 0.31 & 0.33 & 0.34 & 0.38 & 0.43 \\
N-W tstat (Alpha-hedge) & 1.36 & 1.65 & 1.60 & 1.67 & 1.70 & 1.90 & 2.29 \\
\hline
\end{tabular}

Panel B: With Macro-Finance Factors, $\mathrm{T}=12$

\begin{tabular}{lccccccc}
\hline & RET0 & RET1 & RET2 & RET3 & RET4 & RET5 & RET6 \\
\hline Bottom & 1.19 & 1.22 & 1.21 & 1.24 & 1.28 & 1.31 & 1.26 \\
2 & 1.25 & 1.24 & 1.25 & 1.24 & 1.30 & 1.29 & 1.30 \\
3 & 1.25 & 1.32 & 1.28 & 1.31 & 1.28 & 1.31 & 1.28 \\
4 & 1.25 & 1.35 & 1.36 & 1.34 & 1.34 & 1.31 & 1.33 \\
Top & 1.56 & 1.52 & 1.51 & 1.52 & 1.55 & 1.61 & 1.59 \\
\hline Hedge (top-bottom) & 0.38 & 0.32 & 0.31 & 0.28 & 0.27 & 0.31 & 0.33 \\
FM t-stat & 2.32 & 1.89 & 1.85 & 1.70 & 1.61 & 1.90 & 2.00 \\
Sharpe & 0.10 & 0.09 & 0.08 & 0.08 & 0.07 & 0.09 & 0.09 \\
Alpha-hedge & 0.14 & 0.24 & 0.34 & 0.37 & 0.30 & 0.37 & 0.43 \\
N-W tstat (Alpha-hedge) & 1.21 & 1.41 & 1.74 & 1.91 & 1.55 & 1.94 & 2.30 \\
\hline
\end{tabular}


Panel C: No Macro-Finance Factors, T=6

\begin{tabular}{lccccccc}
\hline & RET0 & RET1 & RET2 & RET3 & RET4 & RET5 & RET6 \\
\hline Bottom & 1.26 & 1.30 & 1.31 & 1.31 & 1.33 & 1.32 & 1.29 \\
2 & 1.37 & 1.40 & 1.40 & 1.43 & 1.42 & 1.43 & 1.40 \\
3 & 1.45 & 1.50 & 1.49 & 1.47 & 1.48 & 1.52 & 1.51 \\
4 & 1.37 & 1.38 & 1.37 & 1.39 & 1.42 & 1.43 & 1.44 \\
Top & 0.96 & 0.98 & 0.96 & 0.97 & 0.99 & 1.04 & 1.02 \\
\hline Hedge (top-bottom) & -0.32 & -0.34 & -0.37 & -0.36 & -0.36 & -0.30 & -0.28 \\
FM t-stat & -1.28 & -1.39 & -1.48 & -1.45 & -1.44 & -1.19 & -1.14 \\
Sharpe & -0.06 & -0.06 & -0.07 & -0.07 & -0.07 & -0.05 & -0.05 \\
Alpha-hedge & -0.51 & -0.46 & -0.34 & -0.18 & -0.24 & -0.23 & -0.17 \\
N-W tstat (Alpha-hedge) & -2.52 & -1.96 & -1.23 & -0.65 & -0.82 & -0.79 & -0.60 \\
\hline
\end{tabular}

Panel D: No Macro-Finance Factors, $\mathrm{T}=12$

\begin{tabular}{lccccccc}
\hline & RET0 & RET1 & RET2 & RET3 & RET4 & RET5 & RET6 \\
\hline Bottom & 1.27 & 1.29 & 1.30 & 1.31 & 1.33 & 1.32 & 1.31 \\
2 & 1.35 & 1.40 & 1.40 & 1.41 & 1.43 & 1.44 & 1.42 \\
3 & 1.49 & 1.48 & 1.49 & 1.48 & 1.49 & 1.52 & 1.51 \\
4 & 1.35 & 1.40 & 1.38 & 1.40 & 1.43 & 1.42 & 1.42 \\
Top & 0.96 & 0.97 & 0.95 & 0.97 & 0.97 & 1.04 & 1.00 \\
\hline Hedge (top-bottom) & -0.33 & -0.34 & -0.37 & -0.35 & -0.37 & -0.30 & -0.32 \\
FM t-stat & -1.33 & -1.38 & -1.52 & -1.44 & -1.52 & -1.23 & -1.33 \\
Sharpe & -0.06 & -0.06 & -0.07 & -0.07 & -0.07 & -0.06 & -0.06 \\
Alpha-hedge & -0.49 & -0.43 & -0.34 & -0.17 & -0.25 & -0.23 & -0.22 \\
N-W tstat (Alpha-hedge) & -2.40 & -1.75 & -1.22 & -0.61 & -0.86 & -0.79 & -0.77 \\
\hline
\end{tabular}

Notes: The table shows the results from forming quintile portfolios sorted after idiosyncratic volatility. In

Panels A and B conditioning on macro-finance factors and in Panels C and D not. 
Table 5: Sub-Sample Cross-Sectional Regressions

Panel A: 1971-1989 With Macro-Finance Factors

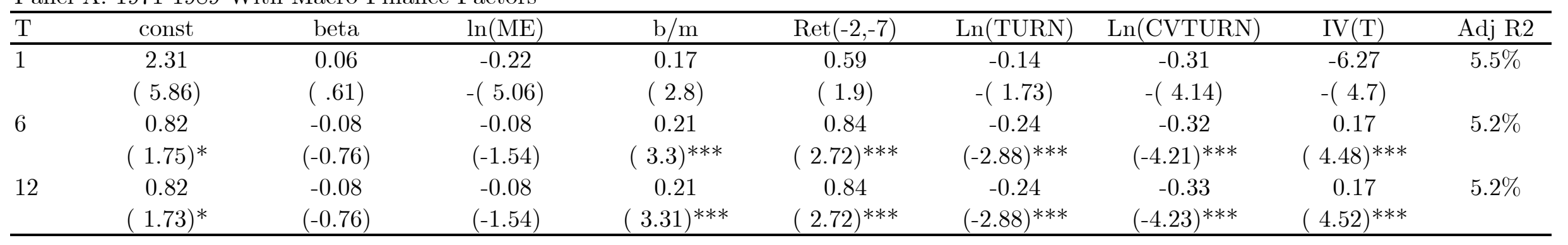

Panel B: 1971-1989 No Macro-Finance Factors

\begin{tabular}{|c|c|c|c|c|c|c|c|c|c|}
\hline$\overline{\mathrm{T}}$ & const & beta & $\ln (\mathrm{ME})$ & $\mathrm{b} / \mathrm{m}$ & $\operatorname{Ret}(-2,-7)$ & Ln(TURN) & Ln(CVTURN) & $\mathrm{IV}(\mathrm{T})$ & Adj R2 \\
\hline \multirow[t]{2}{*}{$\overline{1}$} & 2.40 & 0.07 & -0.23 & 0.17 & 0.57 & -0.14 & -0.31 & -6.79 & $5.5 \%$ \\
\hline & (6.05) & $(.72)$ & $-(5.29)$ & $(2.75)$ & $(1.84)$ & $-(1.67)$ & $-(4.15)$ & $-(5.45)$ & \\
\hline \multirow[t]{2}{*}{6} & 2.36 & 0.06 & -0.23 & 0.17 & 0.57 & -0.14 & -0.31 & -6.55 & $5.6 \%$ \\
\hline & $(5.76)^{* * *}$ & $(0.63)$ & $(-5.12)^{* * *}$ & $(2.79)^{* * *}$ & $(1.85)^{*}$ & $(-1.67)^{*}$ & $(-4.06)^{* * *}$ & $(-5.38) * * *$ & \\
\hline 12 & $\begin{array}{c}2.40 \\
(5.72)^{* * *}\end{array}$ & $\begin{array}{c}0.07 \\
(0.69)\end{array}$ & $\begin{array}{c}-0.23 \\
(-4.99)^{* * *}\end{array}$ & $\begin{array}{c}0.16 \\
(2.76)^{* * *}\end{array}$ & $\begin{array}{c}0.59 \\
(1.9)^{*}\end{array}$ & $\begin{array}{c}-0.14 \\
(-1.67)^{*}\end{array}$ & $\begin{array}{c}-0.30 \\
(-4.07)^{* * *}\end{array}$ & $\begin{array}{c}-7.22 \\
(-5.83)^{* * *}\end{array}$ & $5.6 \%$ \\
\hline
\end{tabular}

Panel C: 1990-2012 With Macro-Finance Factors

\begin{tabular}{|c|c|c|c|c|c|c|c|c|c|}
\hline $\mathrm{T}$ & const & beta & $\ln (\mathrm{ME})$ & $\mathrm{b} / \mathrm{m}$ & $\operatorname{Ret}(-2,-7)$ & Ln(TURN) & Ln(CVTURN) & $\mathrm{IV}(\mathrm{T})$ & Adj R2 \\
\hline \multirow[t]{2}{*}{1} & 2.89 & 0.25 & -0.36 & -0.01 & 0.12 & -0.02 & -0.61 & -4.16 & $5.3 \%$ \\
\hline & $(6.16)$ & ( 2.08$)$ & $-(6.9)$ & $-(.35)$ & $(.33)$ & $-(.17)$ & $-(5.96)$ & $-(2.93)$ & \\
\hline \multirow[t]{2}{*}{6} & 1.35 & 0.15 & -0.22 & 0.01 & 0.25 & -0.14 & -0.71 & 0.13 & $5.0 \%$ \\
\hline & $(3.22)^{* * *}$ & $(1.15)$ & $(-4.13)^{* * *}$ & $(0.2)$ & $(0.66)$ & $(-1.39)$ & $(-6.43)^{* * *}$ & $(4.1)^{* * *}$ & \\
\hline 12 & $\begin{array}{c}1.36 \\
(3.25)^{* * *}\end{array}$ & $\begin{array}{c}0.15 \\
(1.15)\end{array}$ & $\begin{array}{c}-0.23 \\
(-4.16)^{* * *}\end{array}$ & $\begin{array}{c}0.01 \\
(0.2)\end{array}$ & $\begin{array}{c}0.24 \\
(0.66)\end{array}$ & $\begin{array}{l}-0.14 \\
(-1.38)\end{array}$ & $\begin{array}{c}-0.71 \\
(-6.41)^{* * *}\end{array}$ & $\begin{array}{c}0.13 \\
(3.96)^{* * *}\end{array}$ & $5.0 \%$ \\
\hline
\end{tabular}


Panel D: 1990-2012 No Macro-Finance Factors

\begin{tabular}{|c|c|c|c|c|c|c|c|c|c|}
\hline \multirow{3}{*}{$\frac{\mathrm{T}}{1}$} & const & beta & $\ln (\mathrm{ME})$ & $\mathrm{b} / \mathrm{m}$ & $\operatorname{Ret}(-2,-7)$ & Ln(TURN) & Ln(CVTURN $)$ & $\mathrm{IV}(\mathrm{T})$ & Adj R2 \\
\hline & 3.09 & 0.26 & -0.37 & -0.02 & 0.10 & 0.00 & -0.60 & -4.90 & $5.3 \%$ \\
\hline & $(6.92)$ & ( 2.19$)$ & $-(7.27)$ & $-(.5)$ & $(.28)$ & $-(.04)$ & $-(5.79)$ & $-(3.44)$ & \\
\hline \multirow[t]{2}{*}{6} & 3.00 & 0.28 & -0.37 & -0.02 & 0.11 & -0.01 & -0.60 & -4.58 & $5.3 \%$ \\
\hline & $(6.79)^{* * *}$ & $(2.42)^{* *}$ & $(-7.46)^{* * *}$ & $(-0.51)$ & $(0.3)$ & $(-0.11)$ & $(-5.91)^{* * *}$ & $(-2.82)^{* * *}$ & \\
\hline 12 & $\begin{array}{c}3.01 \\
(7.02)^{* * *}\end{array}$ & $\begin{array}{c}0.27 \\
(2.31)^{* *}\end{array}$ & $\begin{array}{c}-0.37 \\
(-7.63)^{* * *}\end{array}$ & $\begin{array}{l}-0.02 \\
(-0.62)\end{array}$ & $\begin{array}{c}0.10 \\
(0.25)\end{array}$ & $\begin{array}{c}-0.01 \\
(-0.12)\end{array}$ & $\begin{array}{c}-0.60 \\
(-5.82)^{* * *}\end{array}$ & $\begin{array}{c}-4.50 \\
(-2.67)^{* * *}\end{array}$ & $5.3 \%$ \\
\hline
\end{tabular}

Notes: The table shows the results from the regression in eq. (5) for two sub-samples and two volatility horizons. */**/*** indicates that the parameter is significant at the 10\%/5\%/1\% level. 
Table 6: Idiosyncratic Skewness Effects

Panel A: With Macro-Finance Factors

\begin{tabular}{|c|c|c|c|c|c|c|c|c|c|c|}
\hline \multirow{3}{*}{$\frac{T}{6}$} & cosnt & beta & $\ln (\mathrm{ME})$ & $\mathrm{b} / \mathrm{m}$ & $\operatorname{Ret}(-2,-7)$ & $\overline{\operatorname{Ln}(\mathrm{TURN})}$ & $\operatorname{Ln}(\mathrm{CVTURN})$ & $\mathrm{IV}(\mathrm{T})$ & Iskewness & Adj R2 \\
\hline & 1.18 & 0.05 & -0.16 & 0.10 & 0.49 & -0.18 & -0.52 & 0.15 & -0.22 & $4.8 \%$ \\
\hline & $(3.71)^{* * *}$ & $(0.53)$ & $(-4.13) * * *$ & $(2.67)^{* * *}$ & $(1.97)^{* *}$ & $(-2.68)^{* * *}$ & $(-7.09)^{* * *}$ & $(6.06)^{* * *}$ & $(-7.06)^{* * *}$ & \\
\hline 12 & $\begin{array}{c}1.18 \\
(3.71)^{* * *}\end{array}$ & $\begin{array}{c}0.05 \\
(0.54)\end{array}$ & $\begin{array}{c}-0.16 \\
(-4.14)^{* * *}\end{array}$ & $\begin{array}{c}0.10 \\
(2.67)^{* * *}\end{array}$ & $\begin{array}{c}0.49 \\
(1.97)^{* *}\end{array}$ & $\begin{array}{c}-0.18 \\
(-2.67)^{* * *}\end{array}$ & $\begin{array}{c}-0.52 \\
(-7.09)^{* * *}\end{array}$ & $\begin{array}{c}0.14 \\
(5.97)^{* * *}\end{array}$ & $\begin{array}{c}-0.22 \\
(-7.05) * * *\end{array}$ & $4.8 \%$ \\
\hline
\end{tabular}

Panel B: No Macro-Finance Factors

\begin{tabular}{|c|c|c|c|c|c|c|c|c|c|c|}
\hline $\mathrm{T}$ & cosnt & beta & $\ln (\mathrm{ME})$ & $\mathrm{b} / \mathrm{m}$ & $\operatorname{Ret}(-2,-7)$ & Ln(TURN) & Ln(CVTURN) & $\mathrm{IV}(\mathrm{T})$ & Iskewness & Adj R2 \\
\hline 6 & 2.77 & 0.19 & -0.31 & 0.07 & 0.30 & -0.06 & -0.45 & -5.46 & -0.21 & $5.1 \%$ \\
\hline & $(8.96)^{* * *}$ & $(2.35)^{* *}$ & $(-8.83)^{* * *}$ & $(1.99)^{* *}$ & $(1.19)$ & $(-0.99)$ & $(-6.67)^{* * *}$ & $(-5.21) * * *$ & $(-7.08) * * *$ & \\
\hline 12 & $\begin{array}{c}2.79 \\
(9.12)^{* * *}\end{array}$ & $\begin{array}{c}0.18 \\
(2.3)^{* *}\end{array}$ & $\begin{array}{c}-0.31 \\
(-8.86)^{* * *}\end{array}$ & $\begin{array}{c}0.07 \\
(1.89)^{*}\end{array}$ & $\begin{array}{c}0.29 \\
(1.17)\end{array}$ & $\begin{array}{l}-0.06 \\
(-01 .)\end{array}$ & $\begin{array}{c}-0.45 \\
(-6.59)^{* * *}\end{array}$ & $\begin{array}{c}-5.74 \\
(-5.29)^{* * *}\end{array}$ & $\begin{array}{c}-0.21 \\
(-7.15)^{* * *}\end{array}$ & $5.1 \%$ \\
\hline
\end{tabular}

Notes: The table shows the results from estimating the regression in eq. (5) extended with the idiosyncratic skewness. */**/*** indicates that the parameter is significant at the $10 \% / 5 \% / 1 \%$ level. 
Table 7: Alternative Volatility Specifications With Macro-Finance Factors

Panel A: BBGK Model

\begin{tabular}{|c|c|c|c|c|c|c|c|c|c|}
\hline $\mathrm{T}$ & cons & beta & $\ln (\mathrm{ME})$ & $\mathrm{b} / \mathrm{m}$ & $\operatorname{Ret}(-2,-7)$ & Ln(TURN) & Ln(CVTURN) & $\mathrm{IV}(\mathrm{T})$ & Adj R2 \\
\hline \multirow[t]{2}{*}{1} & 1.80 & 0.11 & -0.23 & 0.09 & 0.41 & -0.13 & -0.47 & -4.10 & $4.8 \%$ \\
\hline & $(5.47)^{* * *}$ & $(1.23)$ & $(-6.1)^{* * *}$ & $(2.35)^{* *}$ & ( 1.63$)$ & $(-1.89)^{*}$ & $(-6.68)^{* * *}$ & $(-4.94)^{* * *}$ & \\
\hline \multirow[t]{2}{*}{6} & 1.05 & 0.04 & -0.16 & 0.10 & 0.53 & -0.19 & -0.54 & 0.15 & $4.7 \%$ \\
\hline & $(3.38) * * *$ & $(0.48)$ & $(-4.01)^{* * *}$ & $(2.78)^{* * *}$ & $(2.12)^{* *}$ & $(-2.88) * * *$ & $(-7.36)^{* * *}$ & $(6.05)^{* * *}$ & \\
\hline \multirow[t]{2}{*}{12} & 1.03 & 0.04 & -0.15 & 0.10 & 0.53 & -0.19 & -0.54 & 0.15 & $4.7 \%$ \\
\hline & $(3.3)^{* * *}$ & $(0.47)$ & $(-3.99)^{* * *}$ & $(2.78)^{* * *}$ & $(2.14)^{* *}$ & $(-2.92)^{* * *}$ & $(-7.41)^{* * *}$ & $(6.19)^{* * *}$ & \\
\hline
\end{tabular}

Panel B: EGARCH Model

\begin{tabular}{|c|c|c|c|c|c|c|c|c|}
\hline cons & beta & $\ln (\mathrm{ME})$ & $\mathrm{b} / \mathrm{m}$ & $\operatorname{Ret}(-2,-7)$ & Ln(TURN) & Ln(CVTURN) & IV & Adj R2 \\
\hline 1.13 & 0.05 & -0.16 & 0.10 & 0.52 & -0.19 & -0.53 & 0.15 & $4.7 \%$ \\
\hline$(3.59)^{* * *}$ & $(0.56)$ & $(-4.09)^{* * *}$ & $(2.85)^{* * *}$ & $(2.12)^{* *}$ & $(-2.85) * * *$ & $(-7.35)^{* * *}$ & $(6.07)^{* * *}$ & \\
\hline
\end{tabular}

Notes: The table shows the results from the regression in eq. (5). In Panel A we use the Brandt, Brav, Graham, and Kumar (2010)

specification in place of eq. (2) and in Panel B we use the EGARCH specification in place of eq. (2).*/**/*** indicates that the parameter is significant at the $10 \% / 5 \% / 1 \%$ level. 
Figure 1A: R-Squared Values for Factors

Factor 1

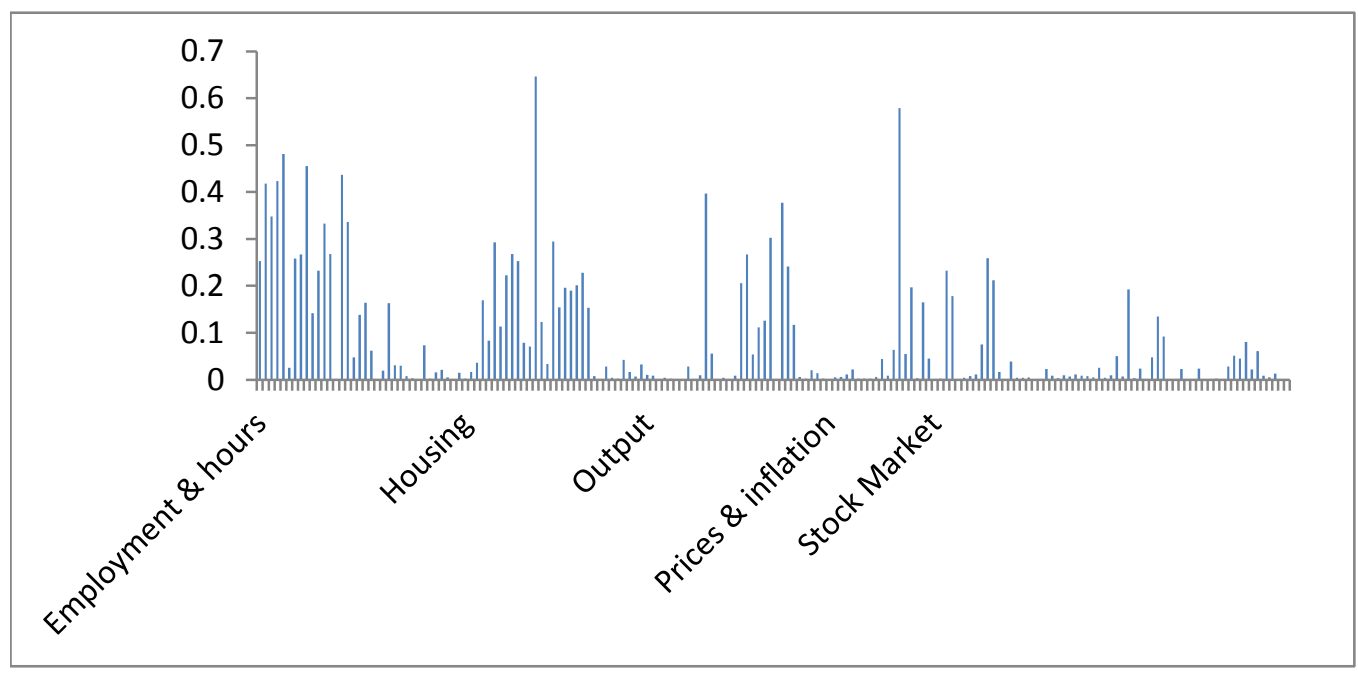

Factor 3

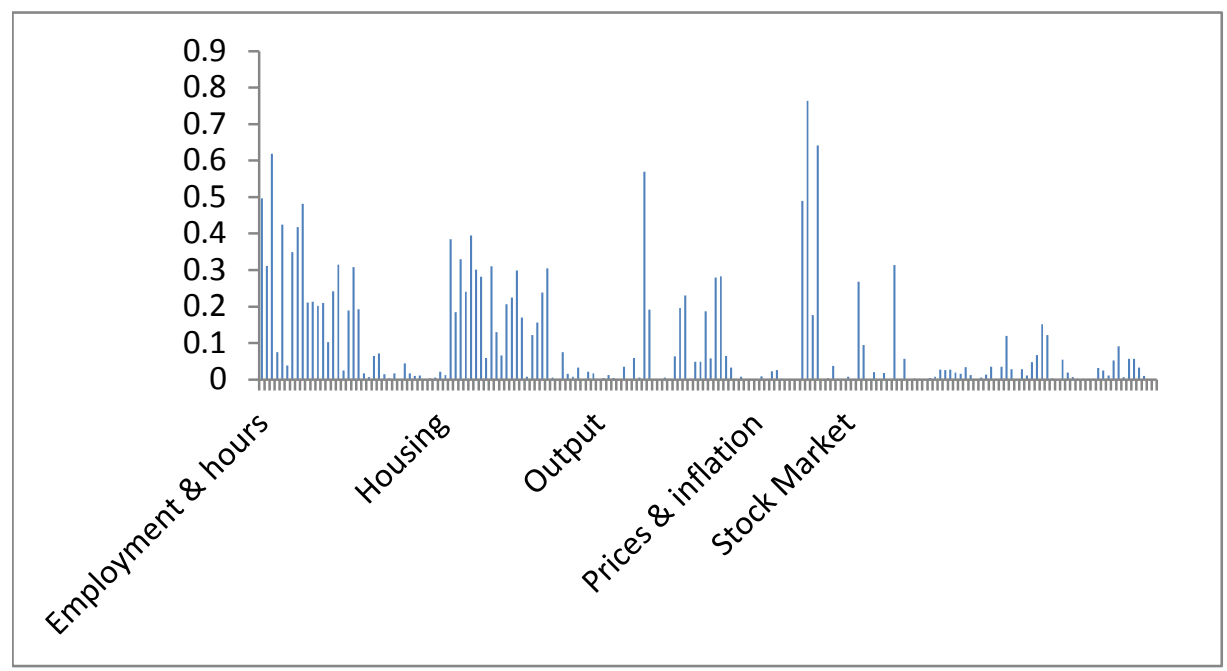

Factor 2

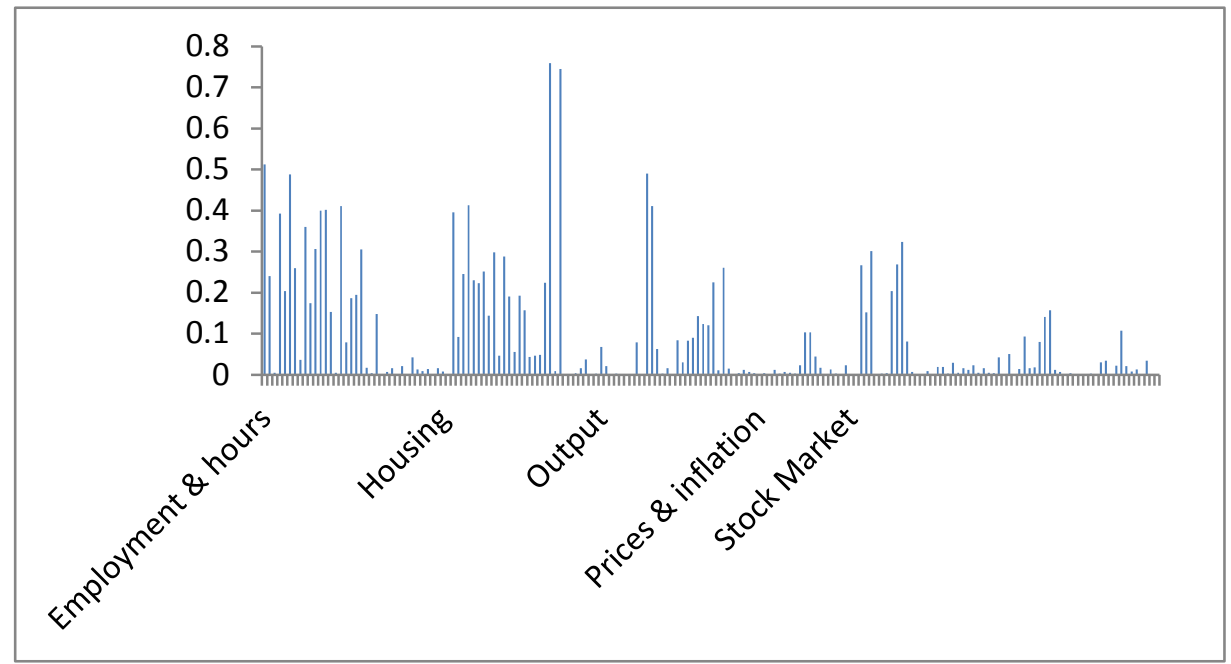

Factor 4

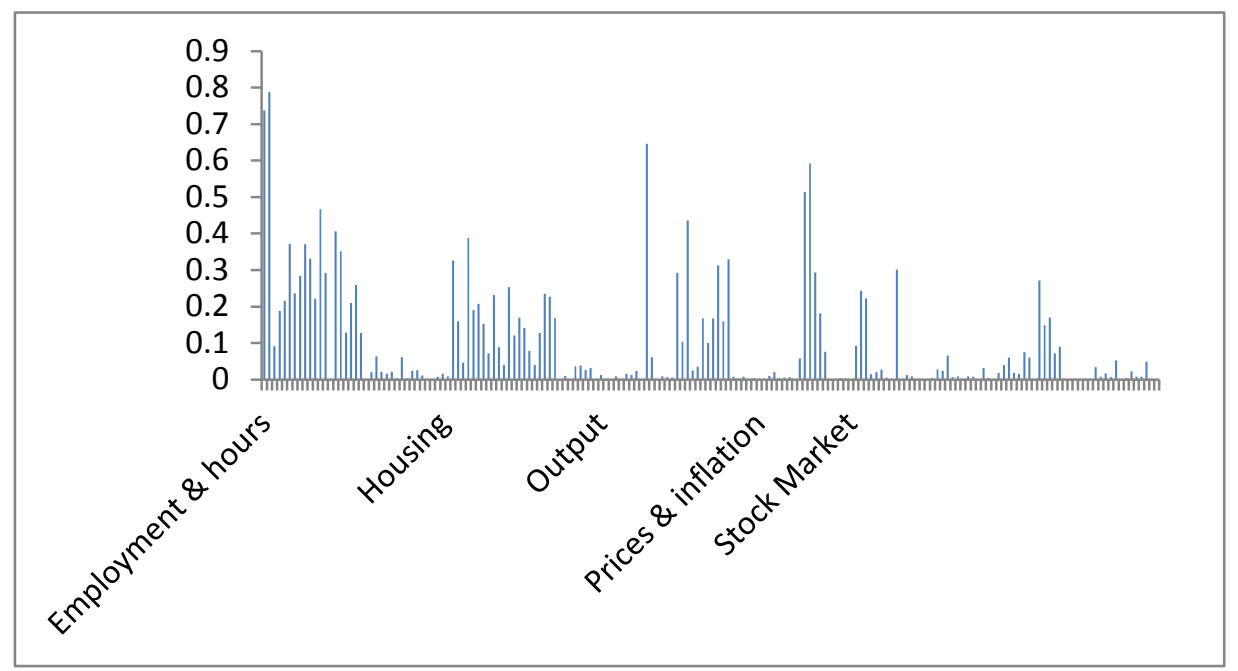


Factor 5

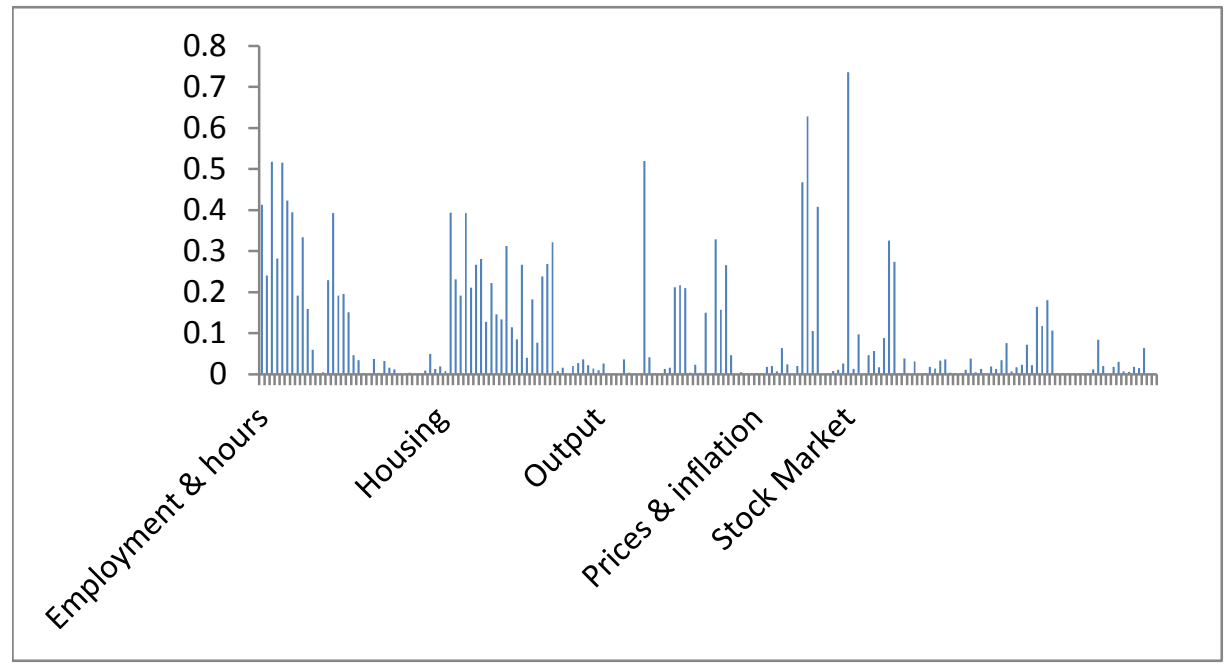

Factor 6

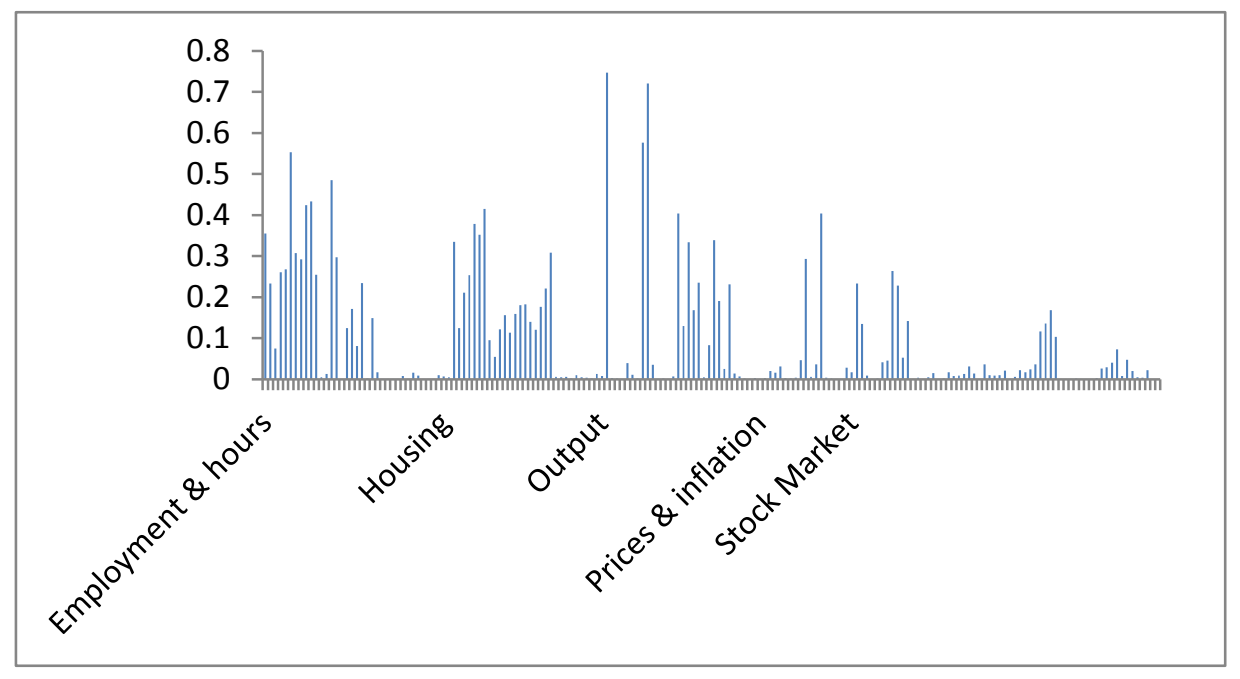


Table 1A: Macro-Finance Variables

\section{Category}

Employment \& hours Employment \& hours Employment \& hours Employment \& hours Employment \& hours Employment \& hours Employment \& hours Employment \& hours Employment \& hours Employment \& hours Employment \& hours Employment \& hours Employment \& hours Employment \& hours Employment \& hours Employment \& hours Employment \& hours Employment \& hours Employment \& hours Employment \& hours Employment \& hours Employment \& hours Employment \& hours Employment \& hours Employment \& hours Employment \& hours Employment \& hours Employment \& hours Employment \& hours Employment \& hours

\section{Variable}

US TOTAL CIVILIAN EMPLOYMENT VOLA

US UNEMPLOYMENT RATE SADJ

US AVERAGE DURATION OF UNEMPLOYMENT (WEEKS) VOLA

US UNEMPLOYED DISTRIBUTION - LESS THAN 5 WEEKS SADJ

US UNEMPLOYED DISTRIBUTION - 5 TO 14 WEEKS SADJ

US UNEMPLOYED FOR 15 WEEKS OR MORE VOLA

US UNEMPLOYED FOR 15 TO 26 WEEKS VOLA

US UNEMPLOYED DISTRIBUTION - 27 WEEKS \& OVER SADJ

US AVERAGE WEEKLY INITIAL CLAIMS - UNEMPLOYMENT INSURANCE CURA

US EMPLOYED - TOTAL PRIVATE VOLA

US EMPLOYED - GOODS-PRODUCING VOLA

US EMPLOYED - MINING VOLA

US EMPLOYED - CONSTRUCTION VOLA

US EMPLOYED - MANUFACTURING VOLN

US EMPLOYED - DURABLE GOODS VOLA

US EMPLOYED - NONDURABLE GOODS VOLA

US EMPLOYED - SERVICE-PROVIDING VOLN

US EMPLOYED - TRADE, TRANSPORTATION, \& UTILITIES VOLA

US EMPLOYED - WHOLESALE TRADE VOLA

US EMPLOYED - RETAIL TRADE VOLA

US EMPLOYED - FINANCIAL ACTIVITIES VOLN

US EMPLOYED - GOVERNMENT VOLN

US AVG WKLY HOURS - TOTAL PRIVATE NONFARM VOLA

US AVG WKLY HOURS - MANUFACTURING VOLA

US AVG OVERTIME HOURS - MANUFACTURING VOLA

US CHICAGO PURCHASING MANAGER DIFFUSION INDEX - EMPLOYMENT NADJ

US AVG HOURLY REAL EARNINGS - CONSTRUCTION CONA

US AVG HOURLY REAL EARNINGS - GOODS-PRODUCING CONA

US AVG HOURLY REAL EARNINGS - MANUFACTURING CONA

US SWISS FRANCS TO US \$ 
Employment \& hours

Employment \& hours

Employment \& hours

Employment \& hours

Employment \& hours

Housing

Housing

Housing

Housing

Housing

Housing

Housing

Housing

Housing

Housing
US JAPANESE YEN TO US \$

US UK $\Theta$ TO US $\$$

US CANADIAN $\$$ TO US $\$$

EM U.S. \$ TO 1 EURO (ECU PRIOR TO 1999)

US WTI CRUDE OIL SPOT PRICE

US NEW PRIVATE HOUSING UNITS STARTED (AR) VOLA

US HOUSING STARTED - NORTHEAST (AR) VOLA

US HOUSING STARTED - MIDWEST (AR) VOLA

US HOUSING STARTED - SOUTH (AR) VOLA

US HOUSING STARTED - WEST (AR) VOLA

US NEW PRIVATE HOUSING UNITS AUTHORIZED BY BLDG.PERMIT (AR) VOLA

US HOUSING PERMITS AUTHORIZED - NORTHEAST (AR) VOLA

US HOUSING PERMITS AUTHORIZED - MIDWEST (AR) VOLA

US HOUSING PERMITS AUTHORIZED - SOUTH (AR) VOLA

US HOUSING PERMITS AUTHORIZED - WEST (AR) VOLA

Interest rates, money \& credit US TREASURY BILL SECONDARY MARKET RATE ON DISCOUNT BASIS-3 MONTH

Interest rates, money \& credit US TREASURY BILL SECONDARY MARKET RATE ON DISCOUNT BASIS- 6 MONTH

Interest rates, money \& credit US FEDERAL FUNDS RATE (AVG.)

Interest rates, money \& credit US PRIME RATE CHARGED BY BANKS

Interest rates, money \& credit US TREASURY CONST MAT 1 YEAR (D) - MIDDLE RATE

Interest rates, money \& credit US TREASURY CONST MAT 5 YEAR (D) - MIDDLE RATE

Interest rates, money \& credit US TREASURY CONST MAT 10 YEAR (W) - MIDDLE RATE

Interest rates, money \& credit US CORPORATE BOND YIELD - MOODY'S AAA, SEASONED ISSUES

Interest rates, money \& credit US CORPORATE BOND YIELD - MOODY'S BAA, SEASONED ISSUES

Interest rates, money \& credit US INTEREST RATE SPREAD-10 YEAR TREASURY BONDS LESS FEDERAL FUND

Interest rates, money \& credit US MONEY STOCK - CURRENCY IN CIRCULATION CURA

Interest rates, money \& credit US MONEY STOCK - SAVINGS DEPOSITS CURA

Interest rates, money \& credit US MONEY STOCK - SMALL TIME DEPOSITS AT COMMERCIAL BANKS CURA

Interest rates, money \& credit US MONEY SUPPLY M2 CURA

Interest rates, money \& credit US MONETARY BASE CURA

Interest rates, money \& credit US REQUIRED RESERVES OF DEPOSITORY INSTITUTIONS CURA

Interest rates, money \& credit US NONBORROWED RESERVES OF DEPOSITORY INSTITUTIONS CURA

Interest rates, money \& credit US COMMERCIAL \& INDUSTRIAL LOANS OUTSTANDING CONA 
Interest rates, money \& credit US COMMERCIAL \& INDL LOANS, NET CHANGE (AR) (BCI 112) CURA

Interest rates, money \& credit US CONSUMER CREDIT OUTSTANDING CURA

Interest rates, money \& credit US CONSUMER INSTALLMENT CREDIT TO PERSONAL INCOME (RATIO) SADJ

Output

Output

Output

Output

Output

Output

Output

Output

Output

Output

Output

Output

Output

Output

Output

Output

Output

Output

Output

Output

Output

Output

Output

Output

Output

Output

Output

Output

Output

Output
US UNIV OF MICHIGAN CONSUMER SENTIMENT - EXPECTATIONS VOLN

US INDUSTRIAL PRODUCTION - TOTAL INDEX VOLA

US INDUSTRIAL PRODUCTION - FINAL PRODUCTS VOLN

US INDL PROD - FINAL PRODUCTS, TOTAL VOLA

US INDL PROD - CONSUMER GOODS VOLA

US INDL PROD - DURABLE CONSUMER GOODS VOLA

US INDL PROD - NONDURABLE CONSUMER GOODS VOLA

US INDUSTRIAL PRODUCTION - BUSINESS EQUIPMENT SADJ

US INDL PROD - MATERIALS VOLN

US INDL PROD - DURABLE GOODS MATERIALS VOLN

US INDL PROD - NONDURB GOODS MATERIALS VOLA

US INDUSTRIAL PRODUCTION - MANUFACTURING (SIC) VOLA

US INDL PROD - RESIDENTIAL UTILITIES VOLA

US INDL PROD - FUELS VOLA

US CHICAGO PURCHASING MANAGER DIFFUSION INDEX-PRODN. (SA) SADJ

US CAPACITY UTILIZATION - MANUFACTURING VOLA

US ISM PURCHASING MANAGERS INDEX (MFG SURVEY) SADJ

US CHICAGO PURCHASING MANAGER DIFFUSION INDEX-NEW ORDERS(SA)

US CHICAGO PURCHASING MANAGER DIFFUSION INDEX-DELIVERIES(SA)

US CHICAGO PURCHASING MANAGER DIFFUSION INDEX-INVENTORIES(SA)

US MANUFACTURERS NEW ORDERS FOR NONDEFENSE CAPITAL GOODS(BCI 27)

US MANUFACTURERS NEW ORDERS - CONSUMER GOODS \& MATERIALS CURA

US MANUFACTURERS NEW ORDERS, DURABLE GOODS CONA

US MANUFACTURERS UNFILLED ORDERS - DURABLE GOODS INDUS. CONA

US MANUFACTURING \& TRADE INVENTORIES CONA

US RATIO OF MFG. \& TRADE INVENTORIES TO SALES CONA

US PERSONAL INCOME (MONTHLY SERIES) (AR) CURA

US PERSONAL INCOME LESS TRANSFER PAYMENTS CONA

US SERVICES, PERSONAL CONSUMPTION EXPENDITURES SADJ

US MANUFACTURING \& TRADE SALES CONA 


\section{Output}

Prices \& inflation Prices \& inflation

Prices \& inflation Prices \& inflation Prices \& inflation Prices \& inflation Prices \& inflation Prices \& inflation Prices \& inflation Prices \& inflation Prices \& inflation Prices \& inflation Prices \& inflation Prices \& inflation Prices \& inflation Prices \& inflation Prices \& inflation Prices \& inflation Stock Market Stock Market Stock Market Stock Market Stock Market Stock Market Stock Market Stock Market Stock Market Stock Market Stock Market Stock Market Stock Market Stock Market
US SALES OF RETAIL STORES CONA

US PPI - FINISHED GOODS SADJ

US PRODUCER PRICE INDEX - FINISHED CONSUMER GOODS SADJ

US PRODUCER PRICE INDEX - INTERMEDIATE MATERIALS SADJ

US PRODUCER PRICE INDEX - CRUDE MATERIALS SADJ

US CPI - COMMODITIES SADJ

US CPI - APPAREL SADJ

US CPI - ALL URBAN: ALL ITEMS SADJ

US CPI - TRANSPORTATION SADJ

US CPI - MEDICAL CARE SADJ

US CPI - DURABLES SADJ

US CPI - SERVICES SADJ

US CPI - ALL ITEMS LESS FOOD SADJ

US CPI - ALL ITEMS LESS SHELTER SADJ

US CPI - ALL ITEMS LESS MEDICAL CARE SADJ

US CHAIN-TYPE PRICE INDEX FOR PCE - DURABLES SADJ

US CHAIN-TYPE PRICE INDEX FOR PCE - NONDURABLE GOODS SADJ

US CHAIN-TYPE PRICE INDEX FOR PCE - SERVICES SADJ

US CHAIN-TYPE PRICE INDEX FOR PERSONAL CONSMPTN.EXPENDITURE SADJ

S\&P 500 COMPOSITE - PRICE INDEX

S\&P INDUSTRIAL - PRICE INDEX

S\&P500 METALS \& MINING - PRICE INDEX

S\&P500 MOVIES \& ENTERTAINMENT - PRICE INDEX

S\&P500 MULTI-LINE INSURANCE - PRICE INDEX

S\&P500 OIL \& GAS EXPLOR \& PROD - PRICE INDEX

S\&P500 PACKAGED FOODS - PRICE INDEX

S\&P500 PERSONAL PRODUCTS SI - PRICE INDEX

S\&P500 PROPERTY \& CASUALTY INSUR - PRICE INDEX

S\&P500 RAILROADS - PRICE INDEX

S\&P500 RESTAURANTS - PRICE INDEX

S\&P500 SOFT DRINKS - PRICE INDEX

S\&P500 SPECIALTY STORES - PRICE INDEX

S\&P500 STEEL - PRICE INDEX 
Stock Market Stock Market Stock Market Stock Market Stock Market Stock Market Stock Market Stock Market Stock Market Stock Market Stock Market Stock Market Stock Market Stock Market Stock Market Stock Market Stock Market Stock Market Stock Market Stock Market Stock Market Stock Market Stock Market Stock Market Stock Market Stock Market Stock Market Stock Market Stock Market Stock Market Stock Market Stock Market Stock Market
S\&P500 TOBACCO SI - PRICE INDEX S\&P500 TRUCKING - PRICE INDEX S\&P 500 EW CONSUMER STAPLES - PRICE INDEX

S\&P 500 EW ENERGY - PRICE INDEX

S\&P 500 EW FINANCIALS - PRICE INDEX S\&P 500 EW HEALTH CARE - PRICE INDEX

S\&P 500 EW I\&T - PRICE INDEX

S\&P 500 EW MATERIALS - PRICE INDEX

S\&P 500 EW T/COMM - PRICE INDEX

S\&P 500 EW UTILITIES - PRICE INDEX

S\&P 500 EW UTILITIES T/COMM - PRICE INDEX

S\&P 500 TELECOM \& IT - PRICE INDEX

S\&P500 AIR FREIGHT \& COURIERS SI - PRICE INDEX

S\&P500 AIRLINES - PRICE INDEX

S\&P500 ALUMINIUM - PRICE INDEX

S\&P500 APPAREL \& ACCESSORIES - PRICE INDEX

S\&P500 APPAREL RETAIL - PRICE INDEX

S\&P500 AUTO PARTS \& EQUIP - PRICE INDEX

S\&P500 AUTOMOBILE MANUFACTURERS - PRICE INDEX

S\&P500 BANKS - PRICE INDEX

S\&P500 BCAST - PRICE INDEX

S\&P500 COMM. EQUIPMENT - PRICE INDEX

S\&P500 COMMERCIAL PRINTING - PRICE INDEX

S\&P500 COMPUTER HWARE - PRICE INDEX

S\&P500 CONSTRUCTION \& ENGINEER SI - PRICE INDEX

S\&P500 DEPARTMENT STORES - PRICE INDEX

S\&P500 DIVERSIFIED FINANCIALS - PRICE INDEX

S\&P500 DIVERSIFIED METALS \& MINING - PRICE INDEX

S\&P500 DRUG RETAIL - PRICE INDEX

S\&P500 ELECTRIC UTILITIES SI - PRICE INDEX

S\&P500 ENVR \& FA CILITIES SERV - PRICE INDEX

S\&P500 FOOD RETAIL - PRICE INDEX

S\&P500 FOOTWEAR - PRICE INDEX 
Stock Market Stock Market Stock Market Stock Market Stock Market Stock Market Stock Market Stock Market Stock Market Stock Market Stock Market Stock Market
S\&P500 GENERAL MERCH STORES - PRICE INDEX S\&P500 GOLD - PRICE INDEX

S\&P500 HEALTH CARE EQUIP - PRICE INDEX

S\&P500 HEALTH CARE FACILITIES - PRICE INDEX S\&P500 HOME IMPROVE RETAIL - PRICE INDEX S\&P500 HOMEBUILDING - PRICE INDEX

S\&P500 HOTELS - PRICE INDEX

S\&P500 HOUSEHOLD PRODUCTS SI - PRICE INDEX S\&P500 HOUSEWARES \& SPECIALTIES - PRICE INDEX S\&P500 INDUSTRIAL CONGLOMERATE SI - PRICE INDEX S\&P500 INTEGRATED OIL \& GAS - PRICE INDEX S\&P500 LIFE \& HEALTH INS - PRICE INDEX 
2014-27: Massimiliano Caporin, Eduardo Rossi and Paolo Santucci de Magistris:

Volatility jumps and their economic determinants

2014-28: $\quad$ Tom Engsted: Fama on bubbles

2014-29: Massimiliano Caporin, Eduardo Rossi and Paolo Santucci de Magistris: Chasing volatility - A persistent multiplicative error model with jumps

2014-30: $\quad$ Michael Creel and Dennis Kristensen: ABC of SV: Limited Information Likelihood Inference in Stochastic Volatility Jump-Diffusion Models

2014-31: $\quad$ Peter Christoffersen, Asger Lunde and Kasper V. Olesen: Factor Structure in Commodity Futures Return and Volatility

2014-32: $\quad$ Ulrich Hounyo: The wild tapered block bootstrap

2014-33: Massimiliano Caporin, Luca Corazzini and Michele Costola: Measuring the Behavioral Component of Financial Fluctuations: An Analysis Based on the S\&P 500

2014-34: $\quad$ Morten Ørregaard Nielsen: Asymptotics for the conditional-sum-of-squares estimator in multivariate fractional time series models

2014-35: Ulrich Hounyo: Bootstrapping integrated covariance matrix estimators in noisy jump-diffusion models with non-synchronous trading

2014-36: Mehmet Caner and Anders Bredahl Kock: Asymptotically Honest Confidence Regions for High Dimensional

2014-37: Gustavo Fruet Dias and George Kapetanios: Forecasting Medium and Large Datasets with Vector Autoregressive Moving Average (VARMA) Models

2014-38: Søren Johansen: Times Series: Cointegration

2014-39: $\quad$ Søren Johansen and Bent Nielsen: Outlier detection algorithms for least squares time series regression

2014-40: $\quad$ Søren Johansen and Lukasz Gatarek: Optimal hedging with the cointegrated vector autoregressive model

2014-41: $\quad$ Laurent Callot and Johannes Tang Kristensen: Vector Autoregressions with Parsimoniously Time Varying Parameters and an Application to Monetary Policy

2014-42: $\quad$ Laurent A. F. Callot, Anders B. Kock and Marcelo C. Medeiros: Estimation and Forecasting of Large Realized Covariance Matrices and Portfolio Choice

2014-43: Paolo Santucci de Magistris and Federico Carlini: On the identification of fractionally cointegrated VAR models with the $F(d)$ condition

2014-44: $\quad$ Laurent Callot, Niels Haldrup and Malene Kallestrup Lamb: Deterministic and stochastic trends in the Lee-Carter mortality model

2014-45: $\quad$ Nektarios Aslanidis, Charlotte Christiansen, Neophytos Lambertides and Christos S. Savva: Idiosyncratic Volatility Puzzle: Influuence of Macro-Finance Factors 